\title{
From a spatial adposition to a grammatical relations' marker: Contact- and context-induced grammaticalization and their interaction
}

\author{
LEENA KOLEHMAINEN \\ University of Eastern Finland
}

\begin{abstract}
This paper is an investigation of grammatical relations' marking that combines the advances of monolingual analysis with cross-linguistic comparison. It examines adpositions as grammatical relations' markers and the linguistic change which leads to the rise of adpositional objects from freely insertable spatial adverbials. This study concentrates on the Finnish adposition perään 'after'. An empirical monolingual corpus analysis shows that perään as a grammatical relations' marker is a productive device for argument linking in contemporary Finnish. In a cross-linguistic comparison, the properties of Swedish, German and Finnish adpositional objects with efter, nach and perään 'after', are studied with regard to the continuum between prototypical freely insertable adverbials and prototypical adpositional objects. A diachronic comparison, in turn, focuses on the development of adpositional objects from spatial adverbials and examines three alternative possibilities for perään: native grammaticalization, contact-induced grammaticalization and the interaction of both language-internal and -external factors.
\end{abstract}

Keywords: cross-linguistic comparison; grammaticalization; contact-induced grammaticalization; adpositional objects; adposition calquing; efter; nach; perään; Swedish; German; Finnish 


\section{Introduction}

Neumann-Holzschuh (2009) discusses conspicuous examples in Canadian French, in which, in consequence of language contact with English, the use of certain French prepositions has been extended to a new context. Similar examples have been discussed by Danchev (1988) in relation to aspects of German language contact with respect to Swiss French prepositions. Neumann-Holzschuh's Canadian data comprise of examples like attendre pour quelqu'un 'wait for someone' and Danchev's Swiss data attendre sur quelqu'un (lit. wait on someone) 'wait for someone' (cf. German auf jemanden warten, lit. on someone wait) in which the French prepositions pour 'for' and sur 'on' are used as markers of grammatical relations with a verb which normally governs a direct object. These examples constitute cases of preposition calquing in which bilingual speakers transfer a grammatical structure from the source language to the recipient language. A similar development has been suggested for particular adpositions in Finnish, which are discussed in this paper.

This paper examines adpositions ${ }^{1}$ as markers of grammatical relations. Its purpose is to study both the status and properties of verb governed adpositions and a development that led to a linguistic change in which a spatial adposition is grammaticalized in order to acquire a new function as an indicator of grammatical relations. The Finnish examples in (1) and (2) illustrate the linguistic phenomenon under discussion. Both examples include adpositional phrases which do not occur in their typical function as complement or adjunct phrases expressing spatial relations. Instead, the meaning of the two adpositions has bleached and is more abstract. In addition, the adpositions in question are verb specific and lexically determined by the two particular verbs. In other words, the two primarily spatial adpositions päälle 'onto' and perään 'after' in (1) and (2) have acquired a new function that assigns a similar relation between the verb and the noun, as morphological cases do in Finnish, cf. (3) and (4):

In this paper, I prefer the term adposition, since their class in Finnish includes both prepositions and postpositions. 
(1) Hän ei ymmärrä autojen päälle. $\mathrm{s}(\mathrm{h}) \mathrm{e}$ not.3sg understand car.PL.GEN onto 'S(h)e does not understand about cars.' (Kielitoimiston sanakirja, s.v. päälle)

(2) Nyt kysytään etenkin osaavien yritysjohtajien perään. now ask.PAss especially skilful.PL.GEN executive-manager.PL.GEN after 'Now skilful executive managers are asked for.' (FTC: Kaleva 19981999)

(3) Ymmärsin kysymyksen.

understood.1sG question.ACC

'I understood the question.'

(4) Kysyin hintaa.

asked.1SG price.PART

'I asked the price.'

In the study of Germanic languages, lexically determined prepositions, which form discontinuous lexemes with their verb governors, have been discussed in greater detail. In English linguistics, they have been called prepositional verbs, and the prepositional phrases which they constitute have been labeled as prepositional objects (cf. e.g. Greenbaum \& Quirk 1990: 338, 345). In German linguistics, the prevailing terms are prepositional object (cf. e.g. Duden Grammatik 2005: 850) and prepositional complement (Präpositivkomplement) (Zifonun et al. 1997: 1093), in the study of Swedish, they are refered to as object like adverbials (objektliknande adverbial) (Teleman et al. 1999: 450). In Finnish linguistics, in which the phenomenon has not attracted any wide attention so far, previous studies do not offer any unambiguous label for examples like (1) and (2). For lack of a better term, in this study I will adopt the term adpositional object in accordance with the English and German linguistic tradition. ${ }^{2}$

\footnotetext{
2 This label is not problem-free because, in Finnish linguistics, the term object has been restricted to cover NPs in grammatical morphological cases. If one, however, considers that adpositions as grammatical relations' markers have been characterized
} 100 
The goal of this paper is twofold: First, I will discuss the status and properties of adpositional objects in contemporary Finnish and study their use in corpora. An additional aspect will be the properties of grammaticalized adpositional objects: what does it mean that an adposition has been grammaticalized to a grammatical relations' marker and what kinds of features reflect its new status? This study concentrates on one particular adposition, which is perään 'after' (cf. 2).

Secondly, this study examines a particular linguistic change in which a spatial adposition undergoes a shift and acquires a new function as an indicator of grammatical relations. Traditionally, Finnish adpositional objects have been regarded as calques of corresponding prepositional phrases in Germanic languages, especially in Swedish - a language which throughout the history has had a strong influence on Finnish. This study considers an alternative approach and discusses the possibility of a native language-internal grammaticalization process that leads to such a change and the interaction of both language-internal and language-external factors. However, due to the lack of historical data on the Finnish language, the results will not be absolutely conclusive and do not allow us to decide unambiguously either way. Still, the most important result of this study is that it shows new ways and possibilities to investigate linguistic changes in Finnish which so far have been believed to be caused by language contact. On a more general level, this paper contributes to the study of the mechanisms of contact-induced grammaticalization and its interaction with language-internal tendencies.

The theoretical framework will be a composition of diverse aspects that originate, on the one hand, from the study of grammaticalization, especially from the study of grammaticalization of adpositional objects, and on the other hand, from the study of contact-induced grammaticalization. Also, methodologically, I will exploit multiple possibilities to approach the subject. The study will include both a monolingual empiri-

as equivalents for morphological cases (cf. VVKS; Merimaa 2007), the chosen term can be justified. In Finnish, one would perhaps prefer the term rektio (cf. German Rektion) to describe the phenomenon. Unfortunately, this does not exist in English. 
cal corpus-analysis of Finnish adpositional objects with the adposition perään 'after' and a cross-linguistic comparison of Swedish, German and Finnish adpositional objects. Both methods are needed for a comprehensive study of the properties of Finnish adpositional objects and for the description of their level of grammaticalization.

The next section provides a crash course in Finnish grammatical relations' marking for readers not familiar with Finnish. Readers fluent in Finnish may wish to skip this and proceed directly to Section 3.

\section{Crash course in Finnish grammatical relations' marking: subject, object and other lexically determined complements of verbs}

For the description of Finnish case marking there are competing approaches whose mutual differences result partly from varying criteria set to identify cases. Traditionally, cases were identified on morphological grounds except for the nominative and the accusative which were defined according both syntactic and on morphological criteria. In more recent studies, the authors have combined morphological criteria with historical ones. Helasvuo (2001) uses such an approach, which, in addition, takes differences between NP-types into account.

TAB LE 1. Cases marking grammatical core functions in Finnish (modeled after Helasvuo 2001: 37)

\begin{tabular}{|l|c|l|l|}
\hline Case & Case ending & \multicolumn{1}{c|}{ Example } & \multicolumn{1}{c|}{ Translation } \\
\hline Nominative & $\varnothing$ & talo, talot & a/the house, (the) houses \\
\hline Accusative & $-n$ & talon & a/the house \\
\hline $\begin{array}{l}\text { Accusative } \\
\text { of pers.pron. }\end{array}$ & $-t$ & minut, meidät & me, us \\
\hline Partitive & $-(t) A$ & taloa, taloja & $\begin{array}{l}\text { (of) a/the house, } \\
\text { (of) (the) houses }\end{array}$ \\
\hline
\end{tabular}


Table 1 summarizes Finnish morphological cases marking grammatical core functions in Helasvuo's study. Except for the accusative, the other cases also inflect in the plural. Note that personal pronouns have a special accusative form.

Table 2 below summarizes the case marking pattern of grammatical core functions according to Helasvuo (2001: 40-56). It shows that only Finnish personal pronouns follow the canonical nominative-accusative coding pattern by having morphologically distinct nominative, accusative and partitive forms. The case marking of full NPs and other pronouns is different.

TABLE 2. Case marking of the grammatical core functions (according to Helasvuo 2001: 43-44)

\begin{tabular}{|l|l|l|}
\hline & Subject & Object \\
\hline Personal pronouns & nominative & accusative or partitive \\
\hline $\begin{array}{l}\text { Other singular pronouns \& } \\
\text { singular full NPS }\end{array}$ & nominative & $\begin{array}{l}\text { accusative or partitive } \\
\text { nominative or partitive }\end{array}$ \\
\hline $\begin{array}{l}\text { Other plural pronouns \& } \\
\text { plural full NPs }\end{array}$ & nominative & nominative or partitive \\
\hline
\end{tabular}

Personal pronouns in the nominative case always function as subjects, those in the accusative and in the partitive as objects. The choice between accusative and partitive is determined by features like boundedness and negation (for a more in depth description of the accusative-partitive alternation cf. e.g. VISK 2004: \$930-\$942):

(5) Minä näin sinut eilen. I saw you.ACC yesterday

'I saw you yesterday'.

(6) Minä en nähnyt sinua eilen I not.1sg saw you.PART yesterday

'I did not see you yesterday'. 
The case marking of full NPs and other pronouns than the personal ones differs from this canonical nominative-accusative pattern. As to them, the number and the presence of a nominative subject have an effect on the marking of grammatical relations. In the singular, if there is a nominative subject present, the object will be distinguished from the subject and it is marked either with the accusative or the partitive (cf. 7). If there is no nominative subject, as, for instance, in passive clauses (cf. 8), there is no need for such a differentiation and the nominative can function as the object case alongside the partitive (Helasvuo 2001: 40-56). The alternation between the nominative and the partitive in the object function depends on the same semantic properties which govern the alternation between the accusative and the partitive object (cf. e.g. VISK 2004: $\$ 930-\$ 942)$.

(7) Mies osti talon / taloa man bought house.ACC / house.PART 'The man bought a house / was buying a house.'

(8) Talo myytiin. / Taloa myytiin kauan. house sell.PASS.PAST house-PART sell.PASS.PAST long 'The house was sold.' 'The house was under sale for a long time.'

Finally in the plural, the grammatical case marking does not unambiguously distinguish between the subject role and the object role of full NPs and pronouns other than personal pronouns, and both the subject and the object can stand in the nominative. The partitive alternates with the nominative in object marking (Helasvuo 2001: 40-56).

(9) Lapset söivät keksit / keksejä. children ate buiscuits / buiscuits.PART 'The children ate all the buiscuits / some buiscuits.'

Additionally, partitive subjects in intransitive clauses must be mentioned, cf. (10), a possibility which most grammars of Finnish reckon with (cf. e.g. VISK 2004: \$910). In Helasvuo’s (2001) study they are treated differently, because they do not trigger agreement: 
(10) Pöytäliinassa on tahroja. tablecloth-INE is spot.PL.PART 'There are spots on the tablecloth.'

Besides the case pattern of grammatical core functions the grammars describe other verb governed complements that occur in local cases. In the latest academic grammar of Finnish (VISK 2004: \$487, \$961, \$1225), they are labeled as rektioadverbiaalit 'lexically determined adverbials'. The term refers to complements whose case is determined by a particular predicate regardless of the nature and meaning of the complement. In valency oriented approaches, these lexically determined complements have been referred to by other terms. Following the model of the German valency grammar tradition, Tarvainen (1985a: 37; 1985b: 129-133) and Hyvärinen (1995) prefer the label local case objects. According to VISK (2004: \$487), the illative case is the most frequent one, cf. (11), but other local cases such as, for example, the elative and the inessive appear as well, cf. (12)-(13). The examples show that the original spatial meaning of the local cases has been bleached in this function.

(11)

Liisa rakastui Markukseen.
Lisa fall-in-love.PAST.3SG Marcus.ILL
'Lisa fell in love with Marcus.

(12) Pidän jäätelöstä.

like.1SG ice-cream.ELA

'I like ice cream.'

(13) Isä auttoi lasta kotiläksyissä.

father helped child.PART homework.INE

'The father helped the child in his/her homework.'

With regard to their status and properties, complements in local cases can be compared with adpositional objects such as those in (1) and (2). Both are lexically determined by particular verbs. Their common features will be discussed more thoroughly in Section 5 . 


\section{Adpositional objects in modern Finnish}

\subsection{Previous studies}

The grammatical descriptions of modern Finnish offer only a scattered and fragmented picture of adpositional objects such as (1) and (2). Most grammars seem to neglect their existence completely, and do not discuss their status, functions and properties at all. In some works, as in Pajunen's study (1999: 146) on the argument structure of Finnish verbs, they are mentioned, but not thoroughly discussed. The latest academic grammar of Finnish (VISK 2004: \$611) touches on them in the discussion of particular adjectives that govern adpositional phrases, cf. (14). In accordance with the above mentioned lexically governed complements in local cases, they are labeled as rektioadverbiaalit 'lexically determined adverbials':

(14) perso makean perään

greedy sweet.gen after

'have a sweet tooth'

Studies focusing on the history of written Finnish show more interest in the phenomenon (cf. e.g. Örnmark 2010; Suutari 2006a; VVKS). This has to do with the fact that the use of adpositions in the oldest written sources of Finnish is strikingly abundant. According to Suutari (2006a), the frequency of adpositions is a characteristic which distinguishes contemporary Finnish from Old Literary Finnish (ca 1540-1820). In addition, one should mention contrastive German-Finnish studies that deal with Finnish adpositional objects. They have been identified by Tarvainen (1985a: 37) and Hyvärinen (1995: 290). Furthermore, Kolehmainen \& Vesalainen (2006) offer a preliminary investigation which presents tentative observations on Finnish adpositional objects as counterparts for prepositional objects in Germanic languages.

Due to the lack of in-depth studies, it is unclear which adpositions can occur in this particular function in modern Finnish. In any case, there seem to be significant differences between individual adpositions. 
Example (1), with the adposition päälle 'onto', seems to represent an isolated and sporadic historical relic in modern Finnish whose use is restricted to the verb ymmärtää 'understand'. But there are productive cases, too. Some adpositional objects seem to belong to a larger series of similar expressions which function as a productive model for the formation of new expressions. For example, the postposition perään 'after' in (2) frequently appears with particular semantic verb groups in contemporary Finnish. This will be shown in the next section.

\subsection{Corpus analysis: perään 'after' as a grammatical relations' marker in contemporary Finnish}

In a particular function, which forms the focus of this study, perään 'after' appears neither as a spatial nor as a temporal adposition. Instead, its function can be best characterized as an indicator of grammatical relations. Examples (15) and (16) illustrate this function of perään, whose English counterpart varies. It seems to be in rather many cases for or another prepositional phrase, or alternatively, a direct object without a preposition:

(15) Niinpä pastori voi keskittyä yksinomaan itseensä ja

'So the Reverend can concentrate totally on himself and'

haikailla nuoruudenrakkautensa perään.

long youth-love.ACC.3PX after

'long for the love of his youth.' (FTC: Kaleva 1998-1999)

(16) Sinead kuolaa Clintonin perään.

Sinead slavers Clinton.gen after

'Sinead is slavering for Clinton.' (FTC: Turun Sanomat 1999)

In examples (15)-(16) above, the perään-phrases express the goal of the activity which the animate referent of the agent subject strives towards. Yet, the referent of the genitive complement of perään is neither affected nor effected by the activity (cf. also Breindl 1989: 57). Instead, it expresses an entity which the agent is attempting to gain possession of. The clauses 
do not reveal whether the agent is successful in this attempt. Örnmark $(2010: 35,58,69)$ describes this particular function of peräan with the keyword "volitional". According to him, clauses such as (15)-(16) above describe an intentional and volitional activity directed towards a particular target which is expressed as the genitive complement of the adposition perä̈n. Tyler \& Evans (2003: 174) describe similar after-phrases in English and contend that they also entail a meaning of being in pursuit of something. According to them, this particular meaning has evolved through a process of pragmatic inference, in which a spatial relation is reinterpreted as an intentional relation. I will return to this issue in Section 4.2.

Kolehmainen \& Vesalainen (2006) state that the perään-phrases quite often seem to replace partitive objects and that they possess a particular semantic nuance which the partitive objects do not have. In the following example pair, the perään-example (17) expresses pursuit of an item someone wishes to attain. This aspect is not included in example (18) with the partitive object, whose referent does not represent an entity one would want to gain possession of. This semantic difference does not come across in the English translations in which the government properties of the verb worry are different.

(17) Turha sis surkutella tuon uuden SE:n perään ---. unnecessary thus worry that.GeN new.GEN Finnish-record.GeN after 'It is thus unnecessary to worry about that new Finnish record.' (FPC)

(18) surkutella elämisen kalleutta worry living expensiveness.PART 'worry about the expensiveness of living'(Kielitoimiston sanakirja: s.v. surkutella)

The examples in this section show that this particular function of perään 'after' is productive in contemporary Finnish, and that the speakers of Finnish have a model at their disposal which they can exploit in order to form new similarly structured expressions with a similar meaning. Some of the combinations of a particular predicate with perä̈n have been lexi- 
calized, and they have been documented in dictionaries for contemporary Finnish. Such cases include examples (2), (14), (19b), (22) and (25). All remaining examples presented in this study represent more or less creative uses which have not yet been lexicalized.

Most examples in this section are taken from the Finnish Text Collection (= FTC) which consists of texts from diverse genres in contemporary Finnish. From this collection, three regional newspapers were chosen for a closer qualitative analysis. The chosen newspapers were Kaleva (1998-1999), Karjalainen (1999), and Turun Sanomat (1999). The size of the chosen corpus was approx. 24 million words, which provided a total of 882 hits for perään. In approx. 190 of these hits, it was possible to determine perä̈n as a grammatical relations' marker which was lexically governed by particular verbs, adjectives or nouns. ${ }^{3}$

The analysis of the corpus hits reveals that there are two semantic verb groups which favor combination with perään. These are, on the one hand, verba sentiendi, which express perception, emotions and cognition, cf. (19). On the other hand, diverse verba dicendi expressing communication, talking, utterances, sounds etc. also occur with perään, cf. (20). Both verb groups are illustrated below by one example, in turn. Verbs which were most frequently combined with perään-phrases in the

3 This figure does not involve hits in which perään 'after' was combined with the verb katsoa 'look' (or its derivations). With katsoa, perään is a verb determined adposition, as well, but this particular combination differs from the other examples in this section in some important respects. First, its meaning is different: it does not entail the above described meaning according to which the subject participant is in pursuit of something. Instead, it refers to a situation of 'taking care of something/someone' or 'watching over something/someone'. Secondly, katsoa + perään-phrase constitutes an idiomatic single expression and it does not belong to a group of similarly structured examples with a similar meaning like the other examples in this section do, cf.:

(i) Vakuutusyhtiöt selvittävät hyvin tarkoin oman alansa piilorikollisuutta, mutta 'Insurance companies work out hidden criminality very exactly in their own field but' yhteiskunta ei vaivaudu katsomaan rahojensa perään. society not.3sG bother look money.PL.3PX after 'the society does not bother to look after its money' (FTC: Kaleva 1998-1999) 
FTC corpus were haikailla 'long' (67 hits), itkeä 'cry' (12 hits), kysellä 'ask (repeatedly)' (48 hits), kysyä 'ask' (18 hits) and olla 'be' (9 hits). All remaining verbs appeared only once or a couple of times. In the presentation below, I will first list the verb types in the texts chosen from the FTC corpus. The FTC verb list is followed by an additional verb list that consists of the verb types in the Finnish Parole Corpus (= FPC) which was included in the study on grounds of comparison. The size of the Finnish Parole Corpus is approx. 180 million words, and it includes newspaper texts, magazines, fiction and non-fiction.

(19a) Verba sentiendi: verb types in FTC: haikailla 'long', haihatella 'daydream', surra 'mourn', ikävöidä 'miss' jonkun/jonkin perään 'after someone/something.'

Additional verb types in FPC: haahuilla 'dream', haaveilla 'dream', hinkua 'hanker,' hohkottaa 'yearn/long/hanker', hätäillä 'worry, haste', palaa 'burn', surkutella 'pity' jonkun/jonkin perään 'after someone/ something.

(19b) Viinasen, Halosen tai Alitalon perään Viinanen.gen Halonen.gen or Alitalo.gen after ei --- yhtiössä enää ikävöity. not.3SG company.INE longer miss.PASS.PAST

'Viinanen, Halonen or Alitalo were not missed in the company anymore.' (FTC: Turun Sanomat 1999)

(20a) Verba dicendi: verb types in FTC: huoata 'mourn/sigh', huokaista 'sigh', huudella 'call/shout', huutaa 'shout/scream', itkeä 'cry', kuuluttaa 'proclaim', kysäistä 'ask (carefully)', kysellä 'ask (repeatedly)', kysyä 'ask', naukua 'mew', soitella 'phone', soittaa 'phone' jonkun/jonkin perään 'after someone/something'.

Additional verb types in FPC: huokailla 'mourn/sigh', läähättää 'gasp', marista 'grumble', kotkottaa 'cackle', porata 'cry', voivotella 'moan' jonkun/jonkin perään 'after someone/something.'

(20b) Hän itkee menetetyn rahan perään.

$s($ he) cries lost.gen money.gen after

'S(he) cries for the lost money' (FTC: Karjalainen 1999) 
In addition, other verbs also allow combination with perään:

(21a) Verb types in FTC: hamuta 'grope', kuolata 'slaver', kytätä 'lurk', olla 'be', surffailla 'surf', sykkiä 'beat', tähyillä 'peer', tuijottaa 'stare' jonkun/ jonkin perään 'after someone/something'.

Additional verb types in FPC: hosua 'rush', jonottaa 'cue', kurkottaa 'strech', sojottaa 'stick out', syyhytä 'itch' jonkun/jonkin perään 'after someone/something.

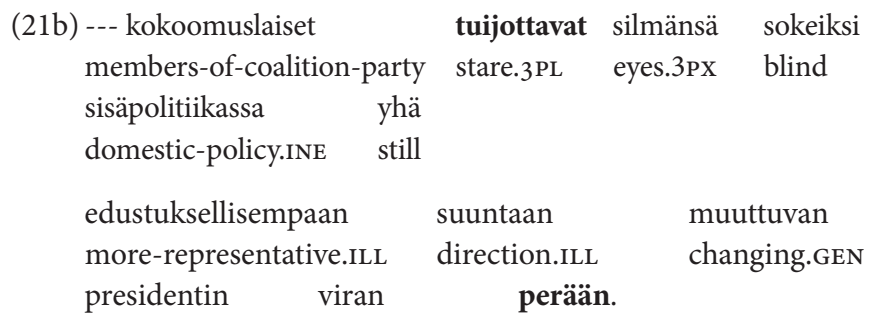

president. GEN office. GEN after

'Members of the coalition party stare their eyes blind when longing for the president office which, (at least) as far as domestic policy is concerned, is changing more and more into a merely representative function.' (FTC: Turun Sanomat 1999)

Finally, perään-phrases occur as complements of particular adjectives, cf. (22)-(23), and verbal nouns which have inherited their argument structure from the verb stem, cf. (24):

(22) Suomalaiset ja unkarilaiset ovat persoja kahvikupillisen perään. Finns and Hungarinas are greedy coffee-cup.GeN after 'Finns and Hungarians have a sweet tooth for a cup of coffee.' (FTC: Kaleva 1998-1999)

(23) Suomalaiset ovat aina olleet kovia auktoriteettien perään. Finns have always been eager authorities.Gen after 'Finns have always been eager to obey authorities.' (FTC: Turun Sanomat 1999) 
(24a) Nouns in FTC: haikailu 'yearn', huuto 'cry/shout', kaipuu 'long', vaatimus 'demand' jonkun/jonkin perään 'after someone/something'.

(24b) --- sillä jo 1970-luvulla kautta Australian heräsi because already 1970s.ADE through Australia. GEN arose vaatimuksia

claims.PART

--- menneisyyden hirmutekojen hyvitysten perään. past.GEN atrocities.GEN reconciliations.GEN after 'Because already in the 1970s claims arose throughout Australia for the reconciliation of atrocities in the past.' (FTC: Kaleva 1998-1999)

These results were complemented by an analysis of perään-hits in the corpus Muoto-opin arkisto ' 'Morphology Archive' (= MA) which consists of dialect samples collected in 160 Finnish villages around the country. This archive consists of approx. 500.000 written notes that represent the use of diverse linguistic features in Finnish dialects.

The examples stored in the Morphology Archive show that the use of the adposition perään 'after' as a grammatical relations' marker is widespread. It occurs both in the Western and in the Eastern dialects, which is the main grouping of Finnish dialects. In the following dialect examples, the brackets include information about the village in which the example was attested. The abbreviations $\mathrm{W}$ and $\mathrm{E}$ indicate whether the village belongs to the Western or Eastern dialects.

In the dialects, the verb olla 'be' is the most frequent verb to occur with perään, cf. (25). Other verbs seem to be rather rare. In the Western dialects the verb kysyä 'ask' appears (cf. 2 above), in the Eastern dialects also the verb hätäillä 'worry', cf. (26):

\footnotetext{
4 I am grateful to Mari Siiroinen for helping me to use the Morphology Archive. The examples are presented in the form they have been stored in the Digital Morphology Archive (available via: http://www.csc.fi) in which, due to technical reasons, the FinnoUgric Transcription System has been slightly changed. The changes are documented at: https://hotpage.csc.fi/su-cgi-bin/appl/ling/dma/dma2.cgi?page=korvausmerkitlb. $\underline{\mathrm{html}}$.
} 
(25) kyl mää ol \e nii\# kovast makki|am perlä et yeah I am so much sweet.GeN after that mää ainaki ota [kaakkua]. I at least take cake.PART

'Yeah, I certainly have a sweet tooth and take cake.' (MA, W: Honkilahti)

(26) hättläelöö nii\# kovasti laena sem perrää. worries so much always it.GEN after 'S(h)e worries always so much about it.' (MA, E: Siilinjärvi)

The analysis of the Morphology Archive samples particularly contributes to the inventory of adjectives. It brings new adjectives into light which can govern perään-phrases and do not occur in the above analyzed corpora representing the Finnish written standard language. Such adjectives are: hullu 'crazy' (W: Artjärvi, Pornainen), sairas 'sick' (E: Hirvensalmi), mahdoton 'impossible/stupendous' (E: Saarijärvi), ahne 'greedy' (E: Kajaani), hurja 'wild, mad' (E: Ruokolahti), innokas 'enthusiastic' (E: Luhanka), villi 'wild' (E: Sysmä) and hanakka 'eager/energetic' (E: Sonkajärvi). They all describe the subject referent's lust or addiction towards the entity expressed in the genitive complement of perään.

Cf. e.g.:

(27) [Lehmät] ne o loikee villi/jä sieni/jem perää. cows they are really wild mushrooms.geN after 'Cows, they really crave for mushrooms.' (MA, E: Sysmä)

(28) se [lapsi] o nii hurja autoloihe perrää. that child is so mad cars.Gen after 'That child is so mad about cars.' (MA, E: Ruokolahti)

\section{Grammaticalization of adpositional objects}

The previous section showed that the postposition perään 'after' is used as a productive device to mark grammatical relations in contemporary Finnish, and that it, in this particular function, expresses the target of the 
activity the agent subject is in pursuit of. This section, in turn, focuses on the question of how this particular function of perään has evolved.

The adposition perään 'after' is the illative case form of the noun perä ${ }^{5}$, whose original meaning is assumed to be 'back part of something, space behind something' (SSA 1995, s.v. perä; Häkkinen 2004, s.v. perä). The original meaning and the accurate path of development of adpositions with the stem perä have recently been under debate. Jaakola (1997: 135-136) presumes that perä originally referred to a body-part ('buttocks, bottom'), and she argues in favor for a linguistic change in which a body-part noun develops into an adposition - a grammaticalization cline which is very common and widespread in the languages of the world (cf. Ojutkangas 2001). Ojutkangas (2005: 545), on her part, rejects this possibility and considers the relational meaning 'back part of something, space behind something' as the starting point of the development. Her study was followed by Suutari (2006b) who compares perä with its cognates in relative languages and contends that the meaning of the noun perä was always relational and never totally concrete. Örnmark's (2010) study, in turn, is a detailed investigation of the development of the noun perä into a spatial (cf. 29) and temporal adposition (cf. 30).

(29) kaik äijä lähtiväs surlem perlä. all men went wolf.gen after 'All men went after the wolf.' (MA, W: Honkilahti)

(30) Kahvit juotiin lounaan perään. coffee.PL drink.PASS.PAST lunch.GEN after 'The coffee was drunk after lunch.' (Örnmark 2010: 69)

According to previous studies, the function of Finnish adpositions as grammatical relations' markers evolved due to language contact which extended the use of adpositions to a new context. It has been claimed that Swedish played the most central role (cf. Saarimaa 1967: 253; Merimaa 2007: 111-113; Häkkinen 1994: 481-482). From the 11th century

Perä is the stem of other postpositions in other cases, as well, e.g. perässä 'perä + inessive', perästä 'perä + elative', which are not dealt with in this paper. 
onwards, the Swedes made crusades into Finland, and in the 14th century, Finland was annexed to the Swedish Kingdom under whose rule it remained until 1809 when it was conquered by Russia and became an autonomous Grand Duchy under the Russian Tsar. Due to this, Swedish was long the dominant language of the nobility, administration and education, and consequently, it has influenced Finnish more than any other language (cf. Paunonen 1997; Tandefelt 1997; Häkkinen 1994; Nau 1995: 40-42). But it is possible that German has influenced Finnish in this respect, too. German-Finnish contacts date back to the Hanseatic League in the Middle Ages during which strong mercantile relations were established between Finnish and North-German tradesmen (cf. e.g. Saarinen 2006; Korhonen 2000; Bentlin 2008: 35-45). Nevertheless, many researchers maintain that the influence of German has more probably taken place via a detour through Swedish (cf. e.g. Korhonen 2000). Bentlin (2008: 7-8), however, stresses that the influence of German on Finnish has largely gone unnoticed and that "[o]nly few linguists have dared deal with this topic until now" (Bentlin 2008: 285). As to the topic of this paper, Swedish and German preposition systems show striking similarities, and with regard to Swedish and German prepositions efter and nach 'after', which are the equivalents for the Finnish perään-phrases, SAOB (s.v. efter) explicitly states that German - and also Dutch - have had an effect on the use and development of the preposition efter in Swedish. Therefore, in the remaining discussion I will not exclude the influence of German.

I will first discuss the mechanisms of contact-induced grammaticalization (4.1). After that I will raise the question about the possibility of a language-internal change: this discussion will especially concentrate on the puzzle of whether a regular context-induced grammaticalization could have been a feasible development and whether the use of perään as a grammatical relations' marker can be motivated by its primary spatial meaning and use as a spatial postposition (cf. 29) (4.2). The final section will examine the possibility of the interaction of both language-external and language-internal factors (4.3). 


\subsection{Contact-induced grammaticalization}

As stated above, Finnish adpositional objects have been regarded as calques of corresponding prepositional phrases in Germanic languages. For instance, Häkkinen (1994: 504) quotes the following example in Gustaf Renvall's Finnish grammar (1840) which demonstrates the Swedish impact on the speech of ordinary people in Western parts of Finland during the first half of the 19th century. In this example, the verb helsata 'greet' represents a loanword and its lexically determined adposition päälle 'onto' calquing (cf. Swedish hälsa på, lit. greet onto 'visit'):

(31) tul helsaman minun päälleen come greet I.GEN onto

'Come and visit me.'

Researchers often refer to the first written documents of Finnish which were religious texts and translated in the 16th century by the Lutheran bishop and religious reformer Mikael Agricola, the founder of the Finnish literary language. Agricola's main achievement was the translation of the New Testament, a task, which required the creation of an entire writing system for Finnish, which did not yet exist. Agricola based his orthography on models of other languages, and, in his texts, their impact is conspicuous. This should come as no surprise as he did not have any native models at his disposal to guide him on how to write Finnish. Suutari (2006a) highlights that source language interference was not necessarily even regarded as a disadvantage at that time. On the contrary, the norms of translation led Agricola to follow the source text as closely and faithfully as possible. In the development of the Finnish language, Agricola's work and texts have, naturally, had an indispensable impact.

Acording to Itkonen-Kaila (1997) and Heininen (1999; 2007), Agricola's translation of the New Testament (Se Wsi Testamenti, 1548) was based on several source texts, on Swedish, German, Greek and Latin Bibles. The Swedish source texts, which, it has been claimed, influenced Agricola's use of Finnish adpositions, were the Swedish New Testament (Thet Nyia Testamentit på Swensko, 1526) and the so-called Gustaf Vasa 
Bible (Biblia, Thet är, All then Helgha Scrifft, på Swensko, 1541). The German source text, in turn, comprised of the German Bible by Martin Luther (Biblia: das ist / die ganze Heilige Schrifft Deudsch, 1534). By comparing Agricola's translation Se Wsi Testamenti with its Swedish and German source texts, it is possible to detect striking parallels which have also been discussed in previous studies on the history of Finnish language.

The following examples (32)-(34) illustrate Agricola's translation of the Swedish and German prepositions efter 'after' and nach 'after'. In (32), an adposition with the stem perä 'after' appears as their counterpart. Example (33) shows that Agricola alternatively used synonymous adpositions with the stem jälki as a Finnish equivalent. From these two options, adpositions with the stem jälki clearly dominated in Agricola's New Testament. In contemporary Finnish, jälkeen 'after' does not seem to appear anymore as a lexically determined adposition indicating grammatical relations: in the monolingual dictionary Nykysuomen sanakirja ([1967] 1992: s.v. jälkeen), jälkeen-phrases occur as an alternative for the partitive object of the verbs surra 'mourn' and itkeä 'cry'. In the more recent dictionary Kielitoimiston sanakirja (2008), they do not appear anymore. Example (34), in turn, shows that the Swedish and German source texts can show differences in the use of prepositions, and that, Agricola in this case, seems to have followed the Swedish source more closely. In the German translation, the preposition auff 'on' occurs instead of nach 'after'. Because these examples are rather long and the glossing of historical data is not an easy task, I have provided them with only a literal translation of the verb and the adposition. In addition, the corresponding Bible verse in the English King James Version (1611/1987) can be found after the other examples.

(32a) Agricola (1548), lit. 'strive after': Ei nin ette mine sen io käsittenyt olen / eli io teudhelinen olen / Mutta mine pyren couan sen pereste / ios mine sen mös madhaisin Käsitte / senielkin quin mine Christuses Jesuses käsitetty olen. 
(32b) Swedish NT (1526), lit. 'step after': Jcke at iagh allredho haffuer thet fattat, eller ath iach fulkomen är, Men iagh trädher fast ther effter, om så kunde skee ath iagh thet ock fatta må, som iagh ock fattat är aff Christo Jesu.

(32c) Swedish Gustaf Vasa's Bible (1541), lit. 'strive after': Jcke at iagh allaredho haffuer thet fattat, eller allaredho fulkommen är, Men iagh faar fast ther effter, om iagh thet ock fatta må, som iagh ock fattat är aff Christo Jesu.

(32d) German Luther Bible (1534), lit. 'chase after': Nicht das ichs schon ergriffen habe/ odder schon volkomen sey/ Ich jage jm aber nach/ ob ichs auch ergreiffen möchte/ nach dem ich von Christo Jhesu ergriffen bin.

(32e) King James Version 1611/1987: Not as though I had already attained, either were already perfect: but I follow after, if that I may apprehend that for which also I am apprehended of Christ Jesus. (Philippians 3:12)

(33a) Agricola (1548), lit. 'long after': ia nin mös heiden Rucouxisans teidhen tedhenne / Jotca mös ikeuöitzeuet teiden ielkin / sen ylenpaltisen Jumalan Armon tedhen quin teisse on

(33b) Swedish NT (1526), lit. 'long after': och teslikes $\mathrm{j}$ theras böner för idher, hwilkom och lengthar effter idher, för then offuerswinnande Gudz nådh, som är $\mathrm{j}$ idher

(33c) Swedish Gustaf Vasa's Bible (1541), lit. 'long after': och teslikes $\mathrm{j}$ theras böner för idher, Hwilka ock lengta effter idher, för then offuerswinnande Gudz nådh, som är j idher

(33d) German Luther Bible (1534), lit. 'seek after': vnd vber jrem gebet fur euch/ welche verlanget nach euch/ vmb der vberschwenglichen gnade Gottes willen jnn euch.

(33e) King James Version 1611/1987: And by their prayer for you, which long after you for the exceeding grace of God in you. (2 Cor. 9:14) 
(34a) Agricola (1548), lit. 'wait after': Sille se ikeue loondocappalein odhotus odhottapi sen Jumalan Lasten ilmoituxen pereste.

(34b) Swedish NT (1526), lit. 'wait after': Ty aht creaturens högheligha åstundan, wänter effter, att Gudz barn skola oppenbaras.

(34c) Swedish Gustaf Vasa’s Bible (1541), lit, 'wait after': Ty creaturens högheligha åstundan, wenter effter, att Gudz barn skola vppenbaras.

(34d) German Luther Bible (1534), lit. 'wait on': Denn das endliche harren der creatur wartet auff die offenbarung der kinder Gottes.

(34e) King James Version 1611/1987: For the earnest expectation of the creature waiteth for the manifestation of the sons of God. (Rom. 8:19)

Örnmark (2010) shows that perään 'after' has functioned as a grammatical relations' marker through the history of Finnish literary language in its all major periods, in Old Literary Finnish (ca 1540-1820), in Early Modern Literary Finnish (ca 1820-1870) and in contemporary Finnish. His quantitative results are especially interesting, according to which the relative frequency of perään as a grammatical relations' marker was higher in Old Literary Finnish than in contemporary Finnish (Örnmark 2008: 75-76). This result indicates that its use was affected by other languages whereby, for instance in translated texts, the norms of translation obliged the early translators to follow the model of the source language as closely as possible. Due to the strategy of faithful translation, the use of perään was extended to contexts, which did not necessarily fully conform to the norms of the target language. This kind of violation of target language norms is not an unusual phenomenon in Translation Studies (cf. e.g. Mauranen 2000; 2006).

Although the use of perään as a grammatical relations' marker has decreased in modern Finnish (Örnmark 2010: 75-76), it is still a productive device, as Section 3 above showed. The decrease does not necessarily constitute a natural development of narrowing. Instead, as Örnmark (2010) states, purist language planning may have influenced the use of 
perään. Probably due to their analytical structure, which was felt foreign in comparison with the dominant synthetic structure of Finnish, adpositional objects have been subject to purist reactions through the history of Finnish language planning (cf. e.g. Lönnrot 1844; Setälä ([1880] 1952: 130-131; Häkkinen 1997: 43), and, for example, Saarimaa (1967: 253) characterizes them as "unnecessary calques from Swedish". Already the translation committee of the first Finnish Bible (1642) replaced a substantial amount of Agricola's adpositions with morphological cases (Rapola 1962: 79-80). Later on, in the beginning of the 19th century, when the first steps in systematic language planning were taken, a range of elements in particular functions, which were claimed to be results of language contact, were stigmatized and banned in Finnish. One such element was the adposition perään (cf. e.g. Lönnrot 1844).

Previous studies which regard the use of adpositions as grammatical relations' markers as a result of external influence, do not, however, discuss the mechanisms of language contact in depth. They illustrate the external impact by comparing Finnish translations with their source texts, often explicitly with the help of Agricola's texts and their sources. Alternatively, they may show that an identically structured expression is available in Swedish and/or in German. Both methods have their weaknesses, but the biggest difficulties in the research pertain to the fact that there are no written documents for Finnish prior to Agricola's translations in the 16th century, the consequence of which is that it is impossible to know exactly what the Finnish language used to be like. A further complicating factor is the lack of non-translated data which complicates the exact estimation of the innovations which were brought about by Agricola and caused by source language interference or which resulted from native language-internal processes.

Because accurate data is not available, one might consider alternative ways to approach the process of language contact that leads to the extension of the use of one particular adposition. One possibility is to relate the linguistic change in question to the mechanisms of contact-induced grammaticalization in general and to examine whether they help us to 
understand the process and result of language contact. This will be done in the remaining part of this section, in which I will focus on the so far assumed mechanisms of contact-induced grammaticalization.

Grammaticalization has been mainly regarded as a language-internal process that causes a linguistic change, but recently, Heine \& Kuteva (2005) have shown that it can also be externally motivated. Their study is critically discussed by researchers who represent other fields; the study of contact linguistics (Johanson 2008), the study of creole languages (Bruyn 2009) and the study of bilingualism (Matthews \& Yip 2009).

According to Heine \& Kuteva (2005), there are three major mechanisms of contact-induced grammaticalization. The so-called ordinary contact-induced grammaticalization is a label for a process in which the starting point for the linguistic change is language contact, but the remaining gradual development is a language-internal process which conforms to the regularities of ordinary grammaticalization. They outline the following cline of development in which $\mathrm{M}$ refers to the model language, $\mathrm{R}$ to the replica language. The first steps (a) and (b) are caused by language contact, the two final steps (c) and (d) are language-internal and can be described with reference to grammaticalization theory. They can, for instance, involve a transition from lexical to grammatical forms or from grammatical into more grammatical forms, the meaning of the changing items may bleach, and the items' use may be extended to a new context. As a whole, it is a creative act in which speakers draw on universal strategies of conceptualization in order to create new structures in language $\mathrm{R}$ (Heine \& Kuteva 2005: 36, 89, 99). The result is the emergence of a linguistic category in the language $\mathrm{R}$ which corresponds to the category available in the model language M. Alternatively, the new category and its functions in the replica language $\mathrm{R}$ may differ from the model language due to the differences in the grammaticalization process (Heine \& Kuteva 2005: 92). 
Ordinary contact-induced grammaticalization (Heine \& Kuteva 2005: 81):

(a) Speakers notice that in language $M$ there is a grammatical category $\mathrm{Mx}$.

(b) They create an equivalent category $\mathrm{Rx}$ in language $\mathrm{R}$ on the basis of the use pattern available in $\mathrm{R}$.

(c) To this end, they draw on universal strategies of grammaticalization, using construction Ry in order to develop Rx.

(d) They grammaticalize Ry to $\mathrm{Rx}$.

Replica grammaticalization is the second type of contact-induced grammaticalization suggested by Heine \& Kuteva (2005). In this mechanism, a grammaticalization process, instead of a category, is transferred from the model language $\mathrm{M}$ to the replica language $\mathrm{R}$. The development and its steps are presented below. In this cline, step (c) distinguishes the replica grammaticalization from the previous mechanism of ordinary contact-induced grammaticalization.

Replica grammaticalization (Heine \& Kuteva 2005: 92):

(a) Speakers notice that in language $M$ there is a grammatical category $\mathrm{Mx}$.

(b) They create an equivalent category $\mathrm{Rx}$ in language $\mathrm{R}$, using material available in $\mathrm{R}$.

(c) To this end, they replicate a grammaticalization process they assume to have taken place in language $\mathrm{M}$, using an analogical formula of the kind [My $>M x]$ : $[R y>R x]$.

(d) They grammaticalize Ry to Rx.

This mechanism is subject to severe criticism in Matthews' \& Yip's (2009) paper. Especially problematic is step (c), which implies metalinguistic awareness of a historical development which is available only to the linguist, but not to a standard bilingual speaker. In addition, the identification of a historical process requires evidence and data which are often not available even to linguists. Matthews \& Yip (2009) conclude that this 
mechanism in Heine's and Kuteva's study has to be reformulated in order to be viable. The same criticism can be found in Johanson's study (2008). He explicitly states that diachronic processes are not accessible to speakers and cannot be copied. Bilingual speakers have access only to the result of a particular grammaticalization process in the model language, and the act of copying does not necessarily mean that the transferred item in the replica language is subject to a similar development. It may develop further, but it does not have to.

The third mechanism suggested by Heine \& Kuteva (2005: 100) is polysemy copying, which Bruyn (2009) labels as apparent grammaticalization, Johanson (2008) as selective copying. The more traditional terms of calquing and loan translation can be regarded as additional synonyms. According to Matthews \& Yip (2009), this process consists of the following steps which do not involve any gradual development in the sense of grammaticalization in the replica language. Rather, a linguistic item in the replica language $B$ is identified to equate with an item in the model language A after which the item in language B is artificially associated with a new meaning and function, i.e., it is re-semantized. The result is the rise of a polysemy pattern of a given item in the replica language.

Polysemy copying (Matthews \& Yip 2009: 368-369):

(a) Grammaticalization of item $\mathrm{X}$ has already occurred in language A.

(b) Item $\mathrm{Y}$ in language $\mathrm{B}$ is identified with item $\mathrm{X}$.

(c) A range of functions is transferred from item $\mathrm{X}$ to item $\mathrm{Y}$.

Applied to the subject of this study, the process of replica grammaticalization can be dismissed on the basis of the criticism directed towards it. However, the two other remaining processes constitute possible developments. Actually, they may be intertwined, because the first two steps (a) and (b) in the process of ordinary contact-induced grammaticalization may be identical to those in polysemy copying (cf. also Matthews \& Yip 2009: 369). This means that polysemy copying can comprise the first stage in ordinary contact-induced grammaticalization in which, first, an 
equivalence relation is established between two particular items in the model language and in the replica language. After this, the item in the replica language is associated with a new meaning and function which correspond to the semantics and functional properties of the model language item. This process may be followed by a language-internal process of grammaticalization owing to which the phenomenon can be extended to new contexts and become gradually productive.

With regard to the adposition perään 'after', the process of ordinary contact-induced grammaticalization would mean that, at the first stage of the development, bilingual speakers notice that the preposition efter 'after' in Swedish and/or nach 'after' in German are used, among their other functions, as grammatical relations' markers, whereby they are lexically governed by particular verbs. In this particular function, efter and nach form phrases which express the goal of the activity the agent subject of the clause is in pursuit of (cf. Teleman et al. 1999: 453; SO: s.v. efter; DWB: s.v. nach). At the next stage, speakers identify the Finnish item perään which they feel to be equivalent and which they start to use in an identical meaning and function. As Johanson (2008: 70) states, once the copied item is conventionalized, it is subject to language-internal processes and may develop further. Among others, its meaning may bleach, and it may be used in a wider range of contexts. In other words, it may follow universal pathways of development, i.e. it may grammaticalize.

Heine \& Kuteva (2005: 1, 9, 17, 108-111) stress that contact-induced change makes use of the same conceptual sources as language-internal grammaticalization and proceeds in accordance with the same principles of unidirectionality and gradualness. The question then arises about how spatial adpositions develop into markers of grammatical relations and how adpositional objects grammaticalize? Furthermore, does perään conform to this general pathway of development? These questions will be studied in the next section, which will focus on internally motivated processes in which a grammatical relations' marker is crystallized out of a spatial adposition. The intriguing result of the discussion is that the 
available data for Finnish perään does not seem to resist the possibility of a language-internal development.

\subsection{Language-internal grammaticalization}

According to Rostila (2005; 2007: 130-163), the rise of adpositional objects constitutes a standard case of context-induced grammaticalization (cf. e.g. Heine 2002; Heine et al. 1991: 65-97) in which a particular linguistic context invites a pragmatic inference and semantic reinterpretation which leads to the rise of a new meaning which in turn is conventionalized. He concentrates on the development of the German spatial adpositions vor 'in front of' and auf'on, onto' into grammatical relations' markers and outlines a path of development in which four major stages can be distinguished. These will be presented below. This discussion will be related to the data that exemplifies the use of the Swedish, German and Finnish adpositions efter, nach and perä̈n 'after'. The data show that their development into grammatical relations' markers is in line with the cline outlined by Rostila (2005; 2007).

The starting point of this development are spatial adpositional phrases which function as freely insertable PP-adjuncts or as directional PP-complements selected by predicates, cf. (35)-(37) (Rostila 2005; 2007). At this stage $I$, the adpositions of the PPs occur in their concrete spatial meaning. In Swedish and German, examples like (35) and (36) illustrate the primary spatial use of the prepositions efter and nach. The Swedish example is taken from the dictionary of the Swedish Academy (= SAOB), the German example from the German dictionary of Jacob and Wilhelm Grimm (= DWB). Both dictionaries describe the etymology of the lemmata and their appearances from the historically earliest possible written sources up to the present. In Finnish, in turn, examples like that in (37), which stems from the Morphology Archive, may have constituted the initial step in the development. The Swedish and Finnish examples describe the location of an item behind the landmark of the adposition; in German, the development has been different, and the 
preposition nach in (36) expresses mere direction towards its landmark. The English equivalent is to. ${ }^{6}$

(35) (Timmerträd) som --- släpades över vattnet efter ekorna. saw-timber which draw.PAss over water after boats 'saw timber which was drawn on the water behind the boats' (SAOB: s.v. efter, 1908)

(36) dô diu maget nâch im gie when the girl after him went 'when the girl went to him' (DWB: s.v. nach, 1205)

(37) tehti ni\# kauhi lautkuarmA, he|losem perlä et --make.PASS.PAST so big board-load horse.GEN after that 'a so big load of board was made behind the horse that ---' (MA, W: Hinnerjoki)

Stage II in the development is pragmatic inference. According to Rostila $(2005 ; 2007)$, the relationship between the predicate and the PP is semantically under-specified and ambiguous in certain contexts. This invites a reinterpretation whereby the language users try to construct a plausible interpretation of the connection between the predicate and the PP. In the following example (38), the perään-phrase is still an expression of the spatial goal. To be more accurate, the actual goal is not involved, but instead, the PP conveys the pathway of the movement whereby the agent subject is following the entity expressed as the landmark of the adposition. Tyler \& Evans (2003: 174) describe the phenomenon as "in tandem alignment", in which both the referent of the agent subject and the landmark of the adposition are facing and moving in the same direction. But at the same time, this example and other similar examples suggest

\footnotetext{
6 The development of the prepositions is also otherwise different. Swedish efter can be traced back to the ieur. stem ap- 'off, away' to which the comparative ieur. suffix -tero is added 'farther off, farther away' (SAOB: s.v. efter; Tyler \& Evans 2003: 173). German nach, in turn, goes back to the adjective/adverb nāh 'near, close to' in Old High German (ca 500-1050). Its semantic change 'near, close to' > 'to, after' seems to be common in languages in general (Heine \& Kuteva 2002: 214; Kluge 1995: s.v. nach; DWB: s.v. nach).
} 
a specific reinterpretation of the semantic relationship between the verb and the PP. In other words, they constitute a so called "bridging context" which is Heine's (2002: 86) characterization of the context which "giv[es] rise to an inference in favour of a new meaning" in the process of grammaticalization. With regard to examples like (38), language users tend to reason and reinterpret the $\mathrm{PP}$ as an expression of the purpose of the activity: the men are moving in order to catch the lynxes. In other words, the relationship between the verb and the PP is reconstructed as a final one, and instead of a mere spatial relation, the PP is associated with a new meaning of pursuit and purpose (cf. also Nau 1995: 140; Tyler \& Evans 2003: 174).

(38) miähet lähti sitter porukalla ilvestem perrää. (MA, W: Kiikka) men went then together lynx.PL.GEN after 'The men went then together after the lynxes. (The men left in order to chase/catch the lynxes.)'

This pragmatic inference is even stronger in cases in which the landmark of the adposition does not move:

(39) --- ribalder --- som på landzbygden --- gå effter almosa. beggers which on countryside go after charity 'Beggers which wander the countryside and beg for charity.' (SAOB: s.v. efter, 1635)

(40) er schickt die magd nach wein he sends the girl after wine 'He sends the girl to bring some wine.' (DWB: s.v. nach, 1584)

(41) ne [miehet] lähti kais suurter rahhaim perrään --those men went maybe big.GEN money.GeN after [Amerikkaan] sitte.

America.ILL then 'Then, those men left for America maybe with a desire for big money'. (MA, W: Kiikka) 
According to Örnmark (2010: 35, 39-40), exactly these kinds of contexts contribute to the rise of the meaning of volitionality which is his term to describe the relationship between the verb and the PP in contexts which lead to the rise of perään as a grammatical relations' marker. He states that, when the landmark does not constitute a physical entity which would move towards, the characteristics of the animate agent, among others his/her volitionality and intentionality are foregrounded. This is another factor which facilitates the new pragmatic inference of pursuit and which may ease the use of the PPs in further new contexts which no longer involve physical movement at all. The following examples illustrate how the use of efter-, nach- and perään-PPs is extended to cover new verbs (cf. 42-43) or nouns (cf. 44). In these examples, the meaning of motion is no longer present. Instead, the idea of pursuing a particular target is more important. (For more examples in Finnish cf. Section 3 above.)

(42) Leta icke efter lyckans ö! seek not after happiness.gen island 'Do not seek for the island of happiness.' (SAOB: s.v. efter, 1882)

(43) schmeckt dir mein kuss? ich denks; die taste you.DAT my kiss I think-it the heiszen lippen glühten nach mehr. hot lips glowed after more 'Did you enjoy my kiss? I think you did. The hot lips glowed for more'. (DWB: s.v. nach, Goethe)

(44) siim mie näin että kui\#ka kova halu ol there I saw that how big lust had woman-too that.GEN cigarette.GEN after naisellakin sen, tupakam peräh.

'There I saw how big a lust for a cigarette even the woman had.' (MA, W: Valkeala)

The thus far outlined cline of development of the adpositional objects with efter, nach and perään fits the normal "laws" of grammaticalization. 
The locus of the linguistic change is a particular context which, according to Heine (2002: 87), is "the crucial factor in shaping new grammatical meanings". The use in new contexts can be regarded as the "prerequisite" for grammaticalization (Heine \& Kuteva 2005: 15). The new context, as was shown, tends to invite new semantic inferences and interpretations, and if the new context is recurrently associated with the new inference, a new linguistic pattern with its own new meaning may emerge (Heine et al. 1991: 70-72; Heine \& Kuteva 2005: 15, 58). The extension to new contexts is accompanied by desemantization due to which the original more concrete source concept bleaches. Previous studies highlight, however, that this process involves not only semantic loss, but also gain, since a new more abstract concept emerges (Heine \& Kuteva 2005: 15, 89; Heine et al. 1991: 21, 108-109). Examples (35)-(37), (39)-(41) and (42)-(44) illustrate this process of desemantization and how it gradually may have proceeded from one context to another.

At stage III, the new meaning, which emerged via the process of context-induced reinterpretation, is conventionalized. This conventionalization is effected by the context. Rostila $(2005 ; 2007)$ states that if the adposition is used frequently in contexts in which the pragmatic inference is plausible the speakers may generalize and conclude that the new pragmatic meaning is actually the default meaning of the construction. Hopper \& Traugott (2003: 82) emphasize the role of the frequency in grammaticalization in general: the inference in question must reoccur frequently in order to have a lasting effect on the meaning of an expression. In fact, stages II and III may be intertwined. Heine (2002: 85) argues that the possibility to be used in new contexts is an indicator for the fact that the conventionalization has - at least to some extent already happened.

The conventionalization of the pragmatic inference is followed by a reanalysis in which the relations in the hierarchical structure undergo a reorganization, and the adposition is re-defined as a part of a discontinuous lexeme consisting of the verb (or the noun or the adjective) and the adposition (cf. the term prepositional verb in English grammars) (Rostila 
$2005 ; 2007)$. In this step, lexicalization may take place, whereby the combination of a particular predicate and the adposition is stored. In Finnish, this has happened to the previous examples (2), (14), (19b), (22) and (25), in which the perään-phrases constitute complements of particular verbs or adjectives and which are also presented in dictionaries for contemporary Finnish. In Swedish and German, the lexicalization concerns a whole group of verbs. (I will return to this issue in Section 5.) Rostila $(2005 ; 2007)$ notes that lexicalization and storage form an important intermediate phase in the grammaticalization of adpositions to grammatical relations' markers. However, if the development stops in this phase, the result is a single expression which belongs to the field of idioms and other phraseological units. If the development, instead, continues and the phenomenon spreads, we are dealing with grammaticalization.

Rostila $(2005$; 2007) argues that the reanalysis is facilitated by the frequent appearance of the adposition with semantically similar predicates. This contributes to the speakers' inference that the adposition is not inter-changeable with another adposition. The repeated appearance in similar contexts boosts the stabilization of the adposition with particular predicates. In other words, it has a bearing on the fact that the adposition becomes a lexically determined, "fossilized" device that links the argument with particular semantic types of predicates. This has been stressed in other studies on grammaticalization, as well, and, for instance, Hopper \& Traugott (2003: 127) state that repeatedly reoccurring combinations of forms tend to be automatized: they are stored and memorized and uttered as blocks.

In the final stage IV, the adposition becomes a more or less productive marker of grammatical relations. Due to analogy and generalization, its use is no longer restricted to individual lexemes. Instead, it can occur with a group of predicates which belong to the same semantic domain. According to Rostila (2005; 2007), the role of the context is, again, crucial and contributes to the productivity: the frequent use of the adposition with semantically similar predicates may lead the speakers to the 
generalization that the adposition can be used with all predicates which belong to the particular semantic domain. This is what seems to have happened in Swedish and in German in which efter- and nach-phrases can appear with several different predicates which, however, share the meaning of pursuit when combined with efter and nach. In Swedish, the classification and grouping of examples in SAOB (s.v. efter) reveals a cline in which efter is first used in a more concrete sense, whereby it is combined with motion verbs. After this, its use expands to other semantic verb groups, to contact verbs (gripa efter 'grab for something'), to verba sentiendi expressing perception, emotions and cognition (vänta efter 'wait for something'), and finally to acoustic and communication verbs (fråga efter 'ask for something'). In German, a similar development is outlined in DWB (s.v. nach), according to which the combination of nach with motion verbs is followed by contact verbs (greifen nach 'reach out for something') and finally by verba sentiendi (e.g. sehnen nach 'long for something', streben nach 'aspire after something'). In Swedish, the transition to more abstract contexts had taken place by the beginning of the 16th century: the earliest examples in SAOB are taken from the first New Testament (1526) and the first Bible (1541). In German, the earliest examples for the new, more abstract use in DWB come from the period of Middle High German (1050-1350). In Finnish, in which the earliest examples can be found in the first written sources for Finnish from the 16th century (cf. Section 4.1 above), a similar development can be assumed.

This section has shown that the Finnish data with the adposition perään do not collide with the possibility of language-internal grammaticalization. Instead, the use of perään as grammatical relations' markers can be motivated by its more primary use as a spatial adposition. Its development conforms to the general cline of context-induced grammaticalization, in which a spatial adposition's use is first extended to a new context, which invites a pragmatic inference and leads to the emergence of a new meaning. This step in the cline is followed by the conventionalization of the new meaning and the lexicalization of the combination 
predicate + adposition. Finally, the new grammatical pattern spreads, in consequence of which the adposition becomes a more or less productive indicator of grammatical relations. In general, this development testifies important parameters which, in the theory of grammaticalization, have been identified to constitute central phenomena in the evolution of new grammatical meanings and forms. Such are the indispensable role of the context, frequency of use, the process of inferencing, semantic bleaching, and the directionality of the development from a more concrete (spatial) concept to a more abstract one (cf. e.g. Heine et al. 1991; Heine 2002; Heine \& Kuteva 2005).

\subsection{Interaction of internal and external motivations in language change}

Finally, the question arises whether the above-described mechanisms of contact- and context-induced change are mutually exclusive. In previous studies on language contact, the researchers have paid attention to the possibility of multiple sources for language change. For example, Laakso (2001) asks whether it is possible to have many mothers and whether a linguistic innovation in the target language can be both language-internally and -externally motivated. Her conclusion is positive, and she states that a language may "prefer those contact-induced innovations that coincide with its own development tendencies or mechanisms". In the same spirit, van Marle (2001) points out that "a potential internal development may be reinforced by an external force". The interface between native development and foreign influence has also been discussed by Aikhenvald (2006: 2, 22, 29, 31), who highlights the generally acknowledged fact that pre-existing structural similarity between the two languages in contact has a strengthening impact (cf. also Thomason \& Kaufman 1988: 52): if the languages in contact share a grammatical construction, language contact may enhance the frequency and productivity of the existing category in the replica language. She continues to claim that the contact-induced grammatical change may be facilitated if the change 
is universal and typologically natural, in other words, if it is anchored in human cognition and constitutes a cognitively natural development. Nau (1995) goes one step further and maintains that the dichotomy between internal change and external change has to be rejected. She justifies her view by arguing that they share common features and in most cases cannot be separated from each other. For example, analogy, which is based on assumed similarity between two linguistic items and often regarded as a language-internal process, enables the extension of a particular innovation to new contexts. However, borrowing and calquing, as language-external processes, exploit the same idea of similarity and analogy, whereby elements of different languages are associated with each other on the basis of their similar properties.

How should we perceive perään as a grammatical relations' marker? Are there any clues which would hint that external and internal motivations could have intertwined and contributed together to the new status of perään? Indeed, there are some circumstances which speak in favor of such an interaction. Namely, when describing the transition from a spatial adposition to a grammatical relations' marker, Örnmark (2010: 58, 66) argues that the Finnish perään-phrases retain their image-schema which can be abstracted from the spatial source concept, cf. (45) vs. (46). Although perään in examples like (46) no longer occurs in its primary spatial meaning, it has not lost its connection to the spatial source construction. Örnmark concludes that if examples such as (46) are a result of language contact, as is claimed by other researchers, they do not collide with the original native spatial meaning because they preserve the original path-schema conveyed by the illative case of the adposition. Örnmark's observation is important because it shows that the new use pattern of perään does not conflict with the older one, but forms its natural follow-up. 
(45) Toinen heistä ampui pankin pihalla henkilöä, 'In the bank yard, the other one shot at a person'

joka yritti lähteä ryöstäjien perään.

who tried go robber.PL.GEN after

'who tried to run after the robbers.' (FTC: Kaleva 1998-1999)

(46) Hänen uudenkarhea Ford Mondeonsa odotteli talon parkkipaikalla, 'His brand new Ford Mondeo waited in the parking area of the house'

mutta Vares ei turhaan hätäillyt kolmikon perään. but Vares not in vain haste trio.geN after 'but Vares did not see any need to haste to pursue the trio.' (FPC)

Another clue for the possible interaction of native and contact-induced grammaticalization are the unexpected tendencies in the data. Örnmark (2010: 38, 42, 75), whose data covers the appearance of perään from the earliest written sources in the beginning of the 16th century up to contemporary Finnish, observes some counterintuitive circumstances: in the earliest written sources, the relative proportion of perään as a spatial adposition is lower than in contemporary Finnish. In the function of a grammatical relations' marker, in turn, its relative proportion is higher in the oldest sources and decreases by modern Finnish. In other words, the data have uncovered a chronologically peculiar progress in which the historically more original spatial use of perään increases and, the other way around, the historically later arisen more abstract use dominates in the earliest written sources. The data speak for a language contact which has influenced the chronological tendencies, and they show that the earliest written sources followed the source language in consequence of which the use of perään was extended to contexts in which it does not occur anymore. This also becomes evident when one analyzes the individual hits for perään as a grammatical relations' marker in the oldest sources. They include verbs which in contemporary Finnish are not combined with it, for example: etsiä 'search', hakea 'seek', kärsiä 'suffer' jonkun/jonkin perään 'after someone/something' (Örnmark 2010: 66). In sum, it seems that the data for perään as a grammatical relations' 
marker conform to the discovery made in contact linguistics according to which language contact may enhance the frequency of an existing category in the replica language.

Due to lack of historical untranslated records prior to Mikael Agricola's texts from the 16th century, it is impossible to draw final conclusions about the chronological order and decide whether language contact, native grammaticalization or their interaction triggered the innovation and lead to the rise of a new use pattern for the adposition perään. Anyway, the data presented in this section seems to provide some promising hints for the interactional approach: they show how language contact and native grammaticalization tend to reinforce one another (cf. Heine \& Kuteva 2005: 24) and how an existing category in the replica language may become more productive due to language contact (Heine \& Kuteva 2005: 44-46, 79-81).

\section{Cross-linguistic comparison: properties of grammaticalized adpositional objects}

In the previous discussion, I have regarded the adposition perään as a grammatical relations' marker without, however, thoroughly justifying this view. This final section deals with this question whose treatment was postponed until this last section because it is in some respect thematically linked with the previous sections on grammaticalization. The most central question is: what are the features which reflect the fact that an adposition has reached the status of a grammatical relations' marker? I will approach this question by comparing the properties of Swedish, German and Finnish efter-, nach- and perään-phrases with each other. In addition, the discussion will include Finnish local cases as grammatical relations' markers which were previously stated to constitute a parallel device of grammatical relations' marking (cf. Section 2). The exact parallels will come to light in this section. The theoretical background especially consists of German studies on adpositional objects in which their features have been investigated in depth. Important sources 
include the work of Hundt (2001), Lerot (1982) and Breindl (1989) (cf. also Zifonun et al. 1997: 1093-1099). The properties discussed in these studies not only constitute language-specific characteristics of adpositional objects, but also ones which can be considered to be common to languages in general. With regard to the properties of Finnish local cases as grammatical relations' markers, I will refer to the latest Finnish grammar Iso suomen kielioppi (2004) (= VISK).

Adpositional objects form a category which cannot be unambiguously distinguished from freely insertable adverbials from which they have evolved (cf. Section 4.2). Likewise, there are no absolutely watertight criteria to define the difference between lexically determined local case phrases and adverbials in Finnish. They form a continuum whose one end consists of prototypical adverbials, the other end of prototypical, "good" representatives of adpositional objects and lexically determined local case phrases. Figure 1 illustrates this continuum which, on the one hand, can be regarded as a diachronic cline that describes the development from adverbials to lexically determined PPs and local phrases, and on the other hand, it depicts the sliding scale between these two ends on a synchronic level.

Freely insertable adverbials

Lexically determined adpositional objects and local case phrases

FIGURE 1. Continuum between adverbials and lexically determined $P P s$ and local case phrases

In Figure I, the categories located at both ends of the continuum have some central properties which can be regarded as prototypical characteristics of the particular class and which help to distinguish the classes from each other. Previous research has tested and discussed several properties from which the following turn out to be more general and do not only constitute language-specific characteristics: (a) semantic and syntactic necessity, (b) semantic bleaching of the adposition and 
the local case, (c) constancy of the adposition and the local case, and (d) verb-specifity of the adposition and the local case. In the following discussion, these properties will be related to the Swedish, German and Finnish PPs with efter, nach and perään, and to Finnish lexically determined local case phrases.

(a) Semantic and syntactic necessity. Hundt (2001: 167-168, 184) and Lerot (1982: 287) point out that in prototypical cases, adpositional objects belong to the proposition of the predicate, and unlike freely insertable adverbials, they are conceptually presumed and present. This feature of semantic necessity does not concern adverbials whose connection to the predicate is looser. With regard to their grammaticalization, the fact that the adpositional objects are anchored to the basic proposition means that their range has been narrowed down: adpositional objects no longer specify the whole situation expressed by the clause, as freely insertable adverbials do. Instead, they occupy argument slots of the predicate. Lexically determined local case phrases in Finnish share this feature with adpositional objects. Their meaning depends on the verb (VISK 2004: \$448).

With regard to the class of adpositional objects with efter, nach and perään, all of them include cases whose arguments form conceptually inalienable parts of the proposition. For instance, in Swedish and German, the verbs sträva and streben 'aspire' (cf. 47-48) presume an entity towards which the activity is directed. In the same way, the Finnish verb haaveilla 'dream' in (49) and (50) presupposes a target. This target is normally realized as a phrase in the elative case, cf. (50). Alternatively, as example (49) shows, it can be expressed as a perään-phrase. Unlike in the other examples (47)-(48) and (50), the form of the perään-phrase is not primarily verb determined, i.e., it is not (yet) possible to claim that it has lexicalized.

(47) sträva efter berömmelse

aspire after fame

'aspire after fame' (NSO: s.v. efter) 
(48) nach Erfolg streben

after success aspire

'aspire after success' (DUW: s.v. streben)

(49) --- 50-vuotiaat ovat joutuneet haaveilemaan työn perään

50-year-people have have-to dream work.GEN after

yli vuoden.

over year.GEN

'People over 50 have had to dream of work over a year.' (FPC)

(50) haaveilla paremmasta elämästä

dream better.ELA life.ELA

'dream of a better life' (Kielitoimiston sanakirja: s.v. haaveilla)

Zifonun et al. (1997: 1096) emphasize that the feature of semantic necessity does not alone allow one to to distinguish lexically determined PPs - or applied to Finnish circumstances, the local case phrases - from adverbials. In other respects, too, it does not concern all cases which belong to the class of Swedish, German and Finnish expressions under comparison. All languages have examples for the creative use of the adpositions and local cases in question. In such examples, the choice of the adposition or the particular local case is not directly in accordance with the basic valency of the predicate. Instead, it can be claimed that it depends on the particular argument structure construction to which the particular predicate has been transferred (cf. VISK 2004: \$961; Goldberg 1995). The following Swedish and German examples (51)-(52) represent new creative uses of the verbs annonsera 'advertise' and abkämmen 'comb', which in these examples occur as verbs of searching. The efterand nach-phrases express the entity which the agent subject attempts to gain in its sphere of control. The Finnish example (53) is similar. It includes the verb jonottaa 'queue' which is normally combined with a partitive object. In (53), its argument is expressed as a perään-phrase. The example pair in (54), in turn, illustrates that lexically determined local cases can also form models for new, creative examples. Finnish fighting verbs govern local case phrases in the elative case which express 
the reason for the fight, cf. (54a). Example (54b) shows that verbs, which primarily are not verbs of fighting, can, for instance in a sporting context, be used as such and combined with an elative phrase.

(51) annonsera efter en ny sekreterare advertise after a new secretary 'advertise for a new secretary' (NSO: s.v. annonsera)

(52) ein Waldstück nach einem Sträfling abkämmen a woodlot after a convict away-comb 'search a woodlot for a convict'(DUW: s.v. abkämmen)

(53) Ensin jonotetaan kassalle ja sitten tavaran perään. first queue.PAss cash-desk.ALL and then goods.gen after 'First one has to queue at the cash desk and then for the goods.' (FPC)

(54a) taistella elämästä ja kuolemasta fight life.ela and death.eLA 'fight for life and death'

(54b) --- silloin kun voitosta kävelee suomalainen. then when victory.eLA walks Finn 'then when a Finn is walking and fighting for the victory.' (HS 10.3.2007, p. B15)

Researchers repeatedly highlight that semantic necessity does not necessarily result in syntactic necessity (cf. e.g. Hundt 2001: 172; Zifonun et al. 1997: 1094). Instead, there are predicate-specific differences. Some adpositional objects and local case phrases constitute compulsory arguments, some facultative. The efter-, nach- and perään-phrases seem to be always more loosely connected to the predicate. However, the group of Finnish lexically determined local case phrases displays variation. Some of them seem to be compulsory (pohjautua johonkin, lit. base something.ILL 'be based on something'), many not.

(b) Semantic bleaching. In prototypical cases, the meaning of the adposition and the local case has been bleached. They no longer occur in their concrete spatial meaning, but are instead more abstract (Hundt 
2001: 173; Lerot 1982: 265; Zifonun et al. 1997: 1096; VISK 2004: \$1225). The desemantization results from the extension to new contexts (cf. Section 4.2 above). This feature concerns all Swedish, German and Finnish expressions under comparison, and several examples can be found in the previous discussion. It is not unusual, however, that the old spatial concept shines through (Hundt 2001: 173; Zifonun et al. 1997: 1096; VISK 2004: \$1225). Due to this, there is no clear-cut boundary between the lexically determined adpositional objects or local case phrases and the freely insertable adverbials.

(c) Constancy of the adposition and the local case. The criterion of the stability of the linguistic form has been regarded as a rather clear property of lexically determined adpositional objects and local case phrases which allows them to be set apart from adverbials. In prototypical cases, only one adposition or local case is possible, i.e., the adposition cannot be replaced by another adposition and the local case is not interchangeable with another local case. The form is fixed because it is determined by the verb. Adverbials, however, are more loosely connected to the verb which does not determine their form (cf. Hundt 2001: 174; Zifonun et al. 1997: 1094-1095; Breindl 1989: 29; Lerot 1982: 265-266; VISK 2004: $\$ 448, \$ 1225)$. Constancy in the form results from the process of grammaticalization in which the lexicalization leads to the storage of the particular predicate and the adposition. Due to analogy and generalization, the use of the adposition may spread so that it can be used with a group of predicates which belong to the same semantic domain (cf. Section 4.2 above). With regard to Finnish lexically determined local case phrases, the preliminary considerations by Nau (1995: 160-172) show that a similar development can be assumed.

In Swedish and German, the lexicalization concerns several semantic groups of verbs. In the Swedish dictionary NSO and in the German dictionary DUW, verbs which govern efter- and nach-phrases can be divided into four semantic groups, into verbs of searching, verba sentiendi (perception, emotion, cognition), verba dicendi (including acoustic verbs and communication verbs in general), and contact verbs, cf. 
(55a)-(55d). Furthermore, diverse other activity verbs are possible, too, cf. (55e).

(55a) SW: söka efter livets mening, lit. search after life's meaning 'search for the meaning of life'

GE: nach den richtigen Worten suchen, lit. search after right words 'search for the right words'

(55b) SW: de lyssnade efter signaler, lit. they listened after signals 'they were listening for signals'

GE: es hungerte ihn nach Anerkennung, lit. it hungered him after recognition 'he hungered for recognition'

(55c) SW: ringa efter taxi, lit. telephone after taxi 'phone for a taxi'

GE: die Kinder schrien nach ihrer Mutter, lit. the children shouted after their mother 'the children shouted for the mother'

(55d) SW: fumla efter cigarettpaketet, lit. fumble after cigarettecase 'fumble for the cigarette case'

GE: nach dem Schalter tappen, lit. after the switch grope 'grope for the switch'

(55e) SW: borra efter olja, lit. drill after oil 'drill for oil'

GE: nach Schwämmen tauchen, lit. after sponges dive dive for sponges'

As was shown in Section 3.2, the use of Finnish perään as a grammatical relations' marker is more restricted and does not concern as many semantic verb groups as efter and nach do. In Finnish, perään seems especially to favor verba sentiendi and verba dicendi, and, additionally, some other activity verbs can be combined with a perään-phrase, too. (For examples cf. Section 3.2.) Finnish local cases as indicators of grammatical relations, in turn, seem to be more often specific to particular individual verbs, but productive, verb-group-specific cases occur among them, as well. For instance, it was mentioned above that the group of Finnish fighting verbs requires the cause for the fight to be expressed in the elative case, cf. examples (54a) and (54b). (For other examples see VISK 2004: \$448.) 
Constancy of the form seems to cause differences between the expressions under comparison. In Swedish, many verbs seem to allow more alternatives. One such verb is mentioned in example (56), which shows that ringa 'phone' can not only be combined with efter, cf. (55c) above, but also with till 'to'. In German, similar variation is available. For example, the verb schreien 'shout' governs both nach (cf. 55c above) and um 'over', cf. (57). In both languages, the exchange of the adposition results in a minor difference in meaning. In Finnish, the lexically determined local cases can be frozen to particular verbs and cannot be changed. One such verb is tykätä 'like' which requires an elative phrase as its companion, cf. (58). Some other verbs, for their part, do allow variation. For instance, haista 'smell' can govern both an ablative and an allative phrase, cf. (59).

(56) ringa till polisen, lit. phone to police 'phone the police'

(57) die Flüchtlinge schrien um Hilfe, lit. the refugees schouted over help 'the refugees shouted for help'

(58) tykätä piimästä, lit. like sour-milk.ELA 'like sour milk'

(59) haista pahalta/pahalle, lit. smell bad.ABL/bad.ALL 'smell bad'

Contrary to efter, nach and Finnish local cases, the adposition perään does not seem to be interchangeable with another adposition. Nonetheless, this does not mean that perään as a grammatical relations' marker would have reached a higher level of grammaticalization. If anything, we are dealing with the fact that the adpositional marking of grammatical relations is probably a rarer phenomenon in Finnish, in general, and it is not even obvious which adpositions would be suitable substitutes. Recall the fact that the adpositional marking of grammatical relations has not been thoroughly studied in Finnish (cf. Section 3.1).

(d) Verb-specifity of the adposition and the local case. This final feature results from the previous one. If the adposition cannot be replaced by another adposition or the local case is not interchangeable 
with another local case, the particular linguistic form is specific to one individual verb. Adverbials, in turn, from which the lexically determined PPs and local case phrases have developed, are not confined to individual verbs. Instead, they are in prototypical cases freely insertable (Hundt 2001: 174). Verb-specifity is a feature which results from the process of grammaticalization in which the frequent appearance of the adposition with semantically similar predicates contributes to the speakers' inference that the adposition is not inter-changeable with another adposition. This, in turn, affects the lexicalization due to which the adposition becomes a frozen, fossilized part of a discontinuous lexeme that consists of the verb and the adposition (cf. Section 4.2).

As was shown above, this feature does not relate strictly to any of the groups under comparison. The Swedish, German and Finnish adpositions efter, nach and perään are not specific to individual verbs, but instead to particular semantic verb groups. Importantly, they are not freely insertable to any kind of verb. However, there are some crosslinguistic differences. Finnish perään does not (yet) constitute the primary way for argument linking for any verb like efter and nach in Swedish and German do. Verbs which in their primary valency require efter- and nach-phrases are, for instance, längta efter 'long for' (Sw.) and streben nach 'aspire after' (Ge.). Finnish lexically determined local case phrases, for their part, are more often verb-specific, but, as the previous discussion shows, they do also include verb-group-specific cases.

Table 3 below summarizes the results of the cross-linguistic comparison. It shows that the Swedish, German and Finnish efter-, nachand perään-phrases constitute intermediate classes on the continuum between prototypical lexically determined adpositional objects and prototypical adverbials. Furthermore, it shows that Finnish lexically determined local case phrases constitute a parallel grammatical device and can be located on the same continuum. Table 3 can be regarded as a cline which reflects the grammaticalization of adpositional objects and lexically determined local case phrases and their development from freely insertable adverbials. 
TABLE 3. Swedish, German and Finnish adpositional objects and lexically determined local case phrases constitute intermediate classes on the continuum between prototypical lexically determined phrases and prototypical adverbials

\begin{tabular}{|c|c|c|c|c|c|c|}
\hline & $\begin{array}{c}\text { Prototypical } \\
\text { properties of } \\
\text { lex. determined } \\
\text { adpositional } \\
\text { objects and local } \\
\text { case phrases }\end{array}$ & efter & nach & perään & $\begin{array}{c}\text { Fi. local } \\
\text { cases }\end{array}$ & $\begin{array}{c}\text { Prototypical } \\
\text { properties of } \\
\text { freely insertable } \\
\text { adverbials }\end{array}$ \\
\hline \multicolumn{7}{|c|}{$\longleftarrow$} \\
\hline $\begin{array}{l}\text { (a) Semantic } \\
\text { and } \\
\text { syntactic } \\
\text { necessity }\end{array}$ & + & $+/-$ & $+/-$ & $+1-$ & $+1-$ & - \\
\hline $\begin{array}{l}\text { (b) Semantic } \\
\text { bleaching }\end{array}$ & + & + & + & + & + & - \\
\hline $\begin{array}{l}\text { (c) Constancy } \\
\text { of the } \\
\text { linguistic } \\
\text { form }\end{array}$ & + & $+/-$ & $+1-$ & $+/ ?$ & $+1-$ & - \\
\hline $\begin{array}{l}\text { (d) Verb- } \\
\text { specifity }\end{array}$ & + & $+/-$ & $+1-$ & - & $+1-$ & - \\
\hline \multicolumn{7}{|c|}{$\longleftrightarrow$} \\
\hline $\begin{array}{l}+ \text { the property i } \\
- \text { the property in } \\
\text { ? the status of th }\end{array}$ & $\begin{array}{l}\text { question applies } \\
\text { question does no } \\
\text { property is not } f\end{array}$ & the & the & & & \\
\hline
\end{tabular}

The examined properties can be exploited when determining and justifying the status of the Finnish perä̈n-phrases. Do they behave more like prototypical adverbials or do they already display more similarities with prototypical adpositional objects? In my opinion, the examined characteristics show that the Finnish perään-phrases have clearly departed the category of freely insertable adverbials and are approaching the function of grammatical adpositional objects in the same way as the Swed- 
ish and German efter- and nach-phrases are. The biggest cross-linguistic differences relate to the productivity: the use of the Swedish and German adpositional objects with efter and nach has been expanded to several semantic verb groups which do not occur with perään-phrases in Finnish. An additional difference concerns the lexicalization: Finnish perään does not constitute the primary means of argument linking for any verb like efter and nach in Swedish and German do.

\section{Conclusions}

This paper investigated adpositions as indicators of grammatical relations and the linguistic change which leads to the rise of adpositional objects from freely insertable spatial adverbials. It concentrated on the Swedish, German and Finnish adpositions efter, nach and perään 'after', and especially with regard to the study of Finnish language, in which adpositional objects have not so far been examined thoroughly, it provided some new insights.

The main methods of the study were monolingual corpus analysis and cross-linguistic comparison. The empirical monolingual corpus analysis focused on the description of perään 'after' as a grammatical relations' marker in diverse corpora whose analysis showed that perään in this function is a productive device of argument linking in contemporary Finnish. Speakers of Finnish have a model at their disposal which they can exploit creatively in order to form new similarly structured perään-expressions with a similar meaning.

The other main method of cross-linguistic comparison was employed both on a synchronic and diachronic level. In the synchronic comparison of Swedish, German and Finnish adpositional objects with efter, nach and perään, a group of properties typical for adpositional objects were examined. This comparison enabled one to determine the status of Finnish perään-phrases on a continuum between prototypical freely insertable adverbials and prototypical adpositional objects. A diachronic comparison, in turn, investigated the grammaticalization of adpositional 
objects and showed how their development constitutes a standard case of context-induced grammaticalization.

As to the development of Finnish adpositional objects, this study considered three possibilities; their native grammaticalization, their development due to language contact, and the interaction of both language-external and -internal factors. The discussion showed that there are arguments in favor for all of them. The available data for Finnish perään were shown to be compatible with the possibility of native grammaticalization, in which a cognitively natural cline of development leads to the emergence of a grammatical relations' marker from a spatial adposition. An investigation of contact-induced change, in turn, revealed that there is no doubt that the Finnish adposition system has been influenced by language contact. With regard to adpositional objects, both ordinary contact-induced grammaticalization and polysemy copying, which are the two main mechanisms of change suggested in previous research, were found to match the circumstances in Finnish. Finally, it was shown that the processes of contact-induced grammaticalization and native context-induced grammaticalization may have been intertwined, hence language contact has enhanced the frequency and productivity of an already existing category. However, due to a lack of historical records for Finnish, it was impossible to draw final conclusions about the chronological order of development. Nevertheless, the discussion of the three alternatives contributed to the study of linguistic change in Finnish in general by pointing out that, besides the traditional comparison of Finnish translations with their source texts, there are new alternative possibilities to approach it. This is the most important result of this study. 
Abbreviations

1 1st person

2 2nd person

3 3rd person

ACC accusative

ADE adessive

ELA elative

GEN genitive
ILL illative
INE inessive
PART partitive
PASS passive
PAST past tense
PL plural
SG singular

\section{References}

Aikhenvald, Alexandra Y. 2006. Grammars in contact: A cross-linguistic perspective. - Alexandra Y. Aikhenvald, R. M. W. Dixon (Eds.). Grammars in Contact. A Cross-linguistic Study. Oxford: Oxford University Press, 1-66.

Bentlin, Mikko 2008. Niederdeutsch-finnische Sprachkontakte. Der lexikalische Einfluß des Niederdeutschen auf die finnische Sprache während des Mittelalters und der frühen Neuzeit. Mémoires de la Société Finno-Ougrienne 256. Helsinki: Société Finno-Ougrienne.

Biblia, Thet är, All then Helgha Scrifft, på Swensko (1541). Upsala: Georgen Richolff.

Biblia: das ist / die ganze Heilige Schrifft Deudsch /. Vollständiger Nachdruck von 1534. Ed. 2003. 2. Das Newe Testament. Köln: Taschen Verlag.

Breindl, Eva 1989. Präpositionalobjekte und Präpositionalobjektsätze im Deutschen. Tübingen: Niemeyer.

Bruyn, Adrienne 2009. Grammaticalization in creoles. Ordinary and not-soordinary cases. - Studies in Language 33 (2), 312-337. doi:10.1075/ sl.33.2.04bru

Danchev, Andrei 1988. Language contact and language change. - Folia Linguistica 22, 37-53. doi:10.1515/flin.1988.22.1-2.37

Duden Grammatik = Duden. Die Grammatik 2005. 7., völlig neu erarbeitete und erweiterte Auflage. Mannheim: Dudenverlag.

DWB = Deutsches Wörterbuch von Jacob Grimm und Wilhelm Grimm 18541960. Leipzig: S. Hirzel. Available at: http://germazope.uni-trier.de/Projects/DWB (24.08.2010).

DUW = Duden Deutsches Universalwörterbuch A-Z 2006. 6. Aufl. (CD-ROM.)

FPC $=$ Finnish Parole Corpus. An electronic document collection of the Finnish language in the 1990's. Compiled by: Department of General Linguistics, 
University of Helsinki; Research Institute for the Languages of Finland (1996-1998). Available via CSC, http://www.csc.fi (24.08.2010).

FTC $=$ Finnish Text Collection. An electronic document collection of the Finnish language containing ca. 130 million tokens. Compiled by: Department of General Linguistics, University of Helsinki; Research Institute for the Languages of Finland; Department of General Linguistics, University of Joensuu; CSC, the Finnish IT Center for Science. Available via CSC, http:// www.csc.fi (24.08.2010).

Goldberg, Adele 1995. Constructions. A Construction Grammar Approach to Argument Structure. Chicago: University of Chicago Press.

Greenbaum, Sidney, Randolph Quirk 1990. A Student's Grammar of the English Language. 2nd impr. Harlow: Longman.

Jaakola, Minna 1997. Genetiivin kanssa esiintyvien adpositioiden kieliopillistumisesta. - Tapani Lehtinen, Lea Laitinen (Eds.). Kieliopillistuminen. Tapaustutkimuksia suomesta. Kieli 12. Helsinki: Helsingin yliopiston suomen kielen laitos, 121-156.

Häkkinen, Kaisa 1994. Agricolasta nykykieleen. Suomen kirjakielen historia. Porvoo: WSOY.

Häkkinen, Kaisa 1997. Mistä sanat tulevat. Suomalaista etymologiaa. 2. painos. Tietolipas 117. Helsinki: Suomalaisen Kirjallisuuden Seura.

Häkkinen, Kaisa 2004. Nykysuomen etymologinen sanakirja. Helsinki: WSOY.

Heine, Bernd 2002. On the role of context in grammaticalization. - Ilse Wischer, Gabriele Diewald (Eds.). New Reflections on Grammaticalization. Typological Studies of Language 49. Amsterdam: Benjamins, 83-101.

Heine, Bernd, Ulrike Claudi, Friederike Hünnemeyer 1991. Grammaticalization. A Conceptual Framework. Chicago: University of Chicago Press.

Heine, Bernd, Tania Kuteva 2002. World Lexicon of Grammaticalization. Cambridge: Cambride University Press. doi:10.1017/CBO9780511613463

Heine, Bernd, Tania Kuteva 2005. Language Contact and Grammatical Change. Cambridge: Cambridge University Press. doi:10.1017/CBO9780511614132

Heininen, Simo 1999. Mikael Agricola raamatunsuomentajana. Suomalaisen Kirjallisuuden Seuran toimituksia 761. Helsinki: Suomalaisen Kirjallisuuden Seura.

Heininen, Simo 2007. Mikael Agricola. Elämä ja teokset. Helsinki: Edita.

Helasvuo, Marja-Liisa 2001. Syntax in the Making: the Emergence of Syntactic Units in Finnish Conversational Discourse. Studies on Discourse and Grammar 9. Amsterdam: Benjamins. 
Hopper, Paul J., Elizabeth Closs Traugott 2003. Grammaticalization. Second edition. Cambridge: Cambridge University Press.

Hundt, Markus 2001. Grammatikalisierungsphänomene bei Präpositionalobjekten in der deutschen Sprache. - Zeitschrift für germanistische Linguistik 29, 167-191. doi:10.1515/zfgl.2001.012

Hyvärinen, Irma 1995. Finnische Lokalkasusobjekte und deutsche Präpositionalobjekte - Strukturelle Äquivalente? Probleme der kontrastiven Valenzanalyse unter besonderer Berücksichtigung der Infinitivsyntax. - Hans-Werner Eroms, Ludwig M. Eichinger (Hrsg.). Dependenz und Valenz. Beiträge zur germanistischen Sprachwissenschaft 10. Hamburg: Buske, 287-312.

Itkonen-Kaila, Marja 1997. Mikael Agricolan Uusi testamentti ja sen erikieliset lähtötekstit. Suomi 184. Helsinki: Suomalaisen Kirjallisuuden Seura.

Johanson, Lars 2008. Remodeling grammar. Copying, conventionalization, grammaticalization. - Peter Siemund, Noemi Kintana (Eds.). Language Contact and Contact Languages. Hamburg Studies on Multilingualism 7. Amsterdam: Benjamins, 61-79.

Kielitoimiston sanakirja 2.0, 2008. (Electronic dictionary of contemporary Finnish.) Ed. by Kotimaisten kielten tutkimuskeskus.

King James Version 1611/1987. Available at: http://www.biblegateway.com/ (24.08.2010).

Kluge, Friedrich 1995. Etymologisches Wörterbuch der deutschen Sprache. Bearbeitet von Elmar Seebold. 23., erw. Auflage. Berlin: de Gruyter.

Kolehmainen, Leena, Marjo Vesalainen 2006. Zum Status der Adpositionalphrasen. Schnittpunkte zwischen Rektion, Phraseologie und Valenzalternation. - Ulrich Breuer, Irma Hyvärinen (Hrsg.). Wörter - Verbindungen. Festschrift für Jarmo Korhonen zum 60. Geburtstag. Frankfurt a.M.: Lang.

Korhonen, Jarmo 2000. Zum Einfluss des Hochdeutschen auf die Lexik und Phraseologie des Finnischen. - Hans-Peter Naumann, Silvia Müller (Hrsg.). Hochdeutsch in Skandinavien. Internationales Symposium, Zürich, 14.-16. Mai 1998. Tübingen: Francke, 99-115.

Laakso, Johanna 2001. Native or borrowed, or both - is it possible to have many mothers? - Word 52 (2), 197-212.

Lerot, Jacques 1982. Die verbregierten Präpositionen in Präpositionalobjekten. Werner Abraham (Hrsg.). Satzglieder im Deutschen. Vorschläge zur syntaktischen, semantischen und pragmatischen Fundierung. Tübingen: Gunter Narr, 261-291.

Lönnrot, Elias 1844. Muukalaisuudesta Suomessa. - Suomi 1844, 159-184. 
MA = Morphology Archive (Muoto-opin arkisto). Dialect samples collected in 160 Finnish villages and consisting of approx. 500.000 written notes representing the use of diverse linguistic items and constructions in Finnish dialects. Available at: Department of Finnish, Finno-Ugrian and Scandinavian Studies, University of Helsinki and via http://www.csc.fi (24.08.2010).

Matthews, Stephen, Virginia Yip 2009. Contact-induced grammaticalization. Evidence from bilingual acquisition. - Studies in Language 33 (2), 366-395. doi:10.1075/sl.33.2.06mat

Mauranen, Anna 2000. Strange strings in translated language: a study on corpora. - Maeve Olohan (Ed.). Intercultural Faultlines. Research Models in Translation Studies 1: Textual and Cognitive Aspects. Manchester: St. Jerome, 119-141.

Mauranen, Anna 2006. Genre, käännös ja korpus. Elämäntaito-oppaat tarkastelussa. - Anne Mäntynen, Susanna Shore, Anna Solin (Toim.). Genre tekstilaji. Tietolipas 213. Helsinki: Suomalaisen Kirjallisuuden Seura, 214-239.

Merimaa, Heidi 2007. Mikael Agricolan kielen muoto- ja lauserakenteen erikoispiirteitä. - Kaisa Häkkinen, Tanja Vaittinen (Toim.). Agricolan aika. Helsinki: BTJ Kustannus, 103-117.

Nau, Nicole 1995. Möglichkeiten und Mechanismen kontaktbewegten Sprachwandels unter besonderer Berücksichtigung des Finnischen. München \& Newcastle: Lincom.

Neumann-Holzschuh, Ingrid 2009. Contact-induced structural change in Acadian and Louisiana French: mechanisms and motivations. - Language et société 129, 47-68. doi:10.3917/ls.129.0047

NSO = Svensk ordbok 1999. Utgiven av Språkdata och Norstedts Ordbok. Tredje upplagan. (CD-ROM.)

Nya Testamentet i Gustaf Vasas Bibel under jämförelse med texten av år 1526 (1941). Utg. av Natan Lindqvist. Stockholm: Svenska Kyrkans Diakonistyrelses Bokförlag.

Nykysuomen sanakirja [1951-1961] 1992. Lyhentämätön kansanpainos. Kolmastoista painos. Osat 1-6. Porvoo: WSOY.

Ojutkangas, Krista 2001. Ruumiinosannimien kieliopillistuminen suomessa ja virossa. SKS toimituksia 845. Helsinki: Suomalaisen Kirjallisuuden Seura.

Ojutkangas, Krista 2005. Viittauskehykset ja tarkastelunäkökulma - miten sijaintia perusakselilla kuvataan? - Virittäjä 4, 525-551.

Örnmark, Olli 2010. Perä-sanan sisäpaikallissijojen kieliopillistuminen. Unpublished MA-Thesis, University of Helsinki. 
Pajunen, Anneli 1999. Suomen verbirektiosta. Verbien argumenttirakenteen jäsenten valinnasta. Turku: University of Turku, Department of General Linguistics.

Paunonen, Heikki 1997. Finland. - Hans Goebl, Peter H. Nelde, Zdenek Stary, Wolfgang Wölck (Eds.). Contact Linguistics. An International Handbook of Contemporary Research. Berlin: Walter de Gruyter, 993-1007.

Rapola, Martti 1962. Vanha kirjasuomi. Toinen, uudistettu painos. Tietolipas 1. Helsinki: Suomalaisen Kirjallisuuden Seura.

Renvall, Gustaf 1840. Finsk Språklära, Enlight den rena Vest-Finska, i Bokspråk vanliga Dialecten. Åbo.

Rostila, Jouni 2005. Zur Grammatikalisierung bei Präpositionalobjekten. - Torsten Leuschner, Tanja Mortelmans, Sarah De Groodt (Hrsg.). Grammatikalisierung im Deutschen. Berlin: Walter de Gruyter, 135-167.

Rostila, Jouni 2007. Konstruktionsansätze zur Argumentmarkierung im Deutschen. Tampere: University of Tampere.

Saarimaa, E. A. 1967. Kielenopas. Seitsemäs painos. Tarkistanut Paavo Pulkkinen. Porvoo \& Helsinki: WSOY.

Saarinen, Hannes 2006. Von der Peripherie ins Zentrum Europas. Deutschland und Finnland im Laufe der Geschichte. - Hartmut E. H. Lenk (Hrsg.). Finland. Vom unbekannten Partner zum Vorbild Europas? Beiträge zur Fremdsprachenvermittlung. Sonderheft 10. Landau: Verlag Empirische Pädagogik, 19-31.

SAOB $=$ Svenska Akademiens Ordbok 1890-. A-TRIVSEL. Svenska Akademien (Ed.). Available at: http://g3.spraakdata.gu.se/saob/ (24.08.2010).

Setälä, E. N. [1880] 1952. Suomen kielen lauseoppi. Kolmastoista painos. Tarkistanut Matti Sadeniemi. Helsinki: Otava.

SO $=$ Svensk ordbok 2009. Utgiven av Svenska Akademien. Stockholm: Svenska Akademien.

Se Wsi Testamenti. 1548. [Translated by Mikael Agricola.] Available at: http:// kaino.kotus.fil (24.08.2010).

SSA = Suomen sanojen alkuperä 1995. Etymologinen sanakirja. 1-3. Helsinki: Suomalaisen Kirjallisuuden Seura \& Kotimaisten kielten tutkimuskeskus.

Suutari, Toni 2006a. Vssut sinna sisse Iumala se Issa? Vieraiden kielten vaikutuksesta vanhaan kirjaviroon ja -suomeen. - Krista Kerge, Maria-Maren Sepper (Eds.). FINEST Linguistics. Proceedings of the Annual Finnish and Estonian Conference of Linguistics. Tallinn, May 6-7, 2004. Tallinn: Tallinn University Press, 410-420. 
Suutari, Toni 2006b. Body-part names and grammaticalization. - Marja-Liisa Helasvuo, Lyle Campbell (Eds.). Grammar from the Human Perspective. Case, Space and Person in Finnish. Current Issues in Linguistic Theory 277. Amsterdam: Benjamins, 101-128.

Tandefelt, Marika 1997. Finnish-Swedish. - Hans Goebl, Peter H. Nelde, Zdenek Stary, Wolfgang Wölck (Eds.). Contact Linguistics. An International Handbook of Contemporary Research. Berlin: Walter de Gruyter, 1007-1014.

Tarvainen, Kalevi 1985a. Kielioppia kontrastiivisesti. Suomesta saksaksi. Jyväskylä: University of Jyväskylä.

Tarvainen, Kalevi 1985b. Kontrastive Syntax Deutsch-Finnisch. Heidelberg: Groos. Teleman, Ulf, Staffan Hellberg, Erik Andersson 1999. Svenska Akademiens grammatik. Stockholm: Svenska Akademien.

Thet Nyia Testamentit på Swensko 1526. Stockholm.

Thomason, Sarah Grey, Terrence Kaufman 1988. Language Contact, Creolization, and Genetic Linguistics. Berkeley: University of California Press.

Tyler, Andre, Vyvyan Evans 2003. The Semantics of English Prepositions. Spatial Scenes, Embodied Meaning and Cognition. Cambridge: Cambridge University Press. doi:10.1017/CBO9780511486517

van Marle, Jaap 2001. American 'Leeg Duits' ('Low Dutch') - a neglected language. - P. Sture Ureland (Ed.). Global Eurolinguistics: European Languages in North America; Migration, Maintenance and Death. Tübingen: Niemeyer, 79-101.

VISK = Auli Hakulinen, Maria Vilkuna, Riitta Korhonen, Vesa Koivisto, Tarja Riitta Heinone, Irja Alho 2004. Iso suomen kielioppi. SKS toimituksia 950. Helsinki: Suomalaisen Kirjallisuuden Seura. Available at: http://scripta. kotus.fi/visk (24.08.2010).

VVKS = Virtuaalinen vanha kirjasuomi. Available at: http://www.vvks.info/ (24.08.2010).

Zifonun, Gisela, Ludger Hoffmann, Bruno Strecker 1997. Grammatik der deutschen Sprache. Berlin: Walter de Gruyter.

\section{Leena Kolehmainen}

University of Eastern Finland

Foreign Languages and Translation Studies

PO Box 111

Fl-80101 Joensuu, Finland

leena.kolehmainen@uef.fi 


\title{
Spatiaalisesta adpositiosta rektion indikaattoriksi: kielikontaktin ja kontekstin virittämä kieliopillistuminen sekä niiden vuorovaikutus
}

\author{
LEENA KOLEHMAINEN \\ Itä-Suomen yliopisto
}

Tässä artikkelissa tarkastellaan kielellistä muutosta, jossa spatiaalista suhdetta ilmaisevasta adpositiosta kehittyy kieliopillinen rektiosuhteen ilmaisin (vrt. esim. kysyä jonkun/jonkin perään). Tutkimus hyödyntää menetelminään sekä yksikielistä korpusanalyysiä että kieltenvälistä vertailua, ja se keskittyy suomen perään-adpositioon ja sen ruotsin- ja saksankielisiin vastineisiin efter ja nach. Myös teoreettinen viitekehys on yhdistelmä, jossa kieliopillistumisen tutkimus kohtaa kielikontaktin virittämän kieliopillistumisen tutkimuksen.

Korpusanalyysissä tarkastellaan perään-adposition käyttöä erilaisissa kirjoitetun ja puhutun kielen aineistoissa. Analyysin perusteella todetaan, että perään on nykysuomessa suhteellisen produktiivinen rektion indikaattori erilaisten adjektiivien (villi jonkin perään), substantiivien (halu jonkin perään) ja erityisesti verbien (itkeä jonkun/jonkin perään) kanssa, joiden yhteydessä sen muodostama lauseke ilmaisee kohdetta, jota lauseen elollinen osallistuja tavoittelee omaan hallintapiiriinsä.

Kieltenvälisessä vertailussa puolestaan rektiosuhdetta ilmaisevien adpositioiden ominaisuudet suhteutetaan adverbiaaleina toimiviin pre- ja postpositiolausekkeisiin, joista edelliset ovat kieliopillistuneet. Vertailun avulla ruotsin, saksan ja suomen efter-, nach- ja perään-lausekkeet sijoitetaan jatkumolle, jonka alkupäässä sijaitsevat prototyyppiset vapaasti lisättävissä olevat spatiaaliset PP-adverbiaalit ja loppupäässä prototyyppiset PP-lausekkeen muotoiset rektiotäydennykset. Rektiotäydennyksinä toimivien PP-lausekkeiden piirteet heijastelevat toisaalta spatiaalista lähtökohtaansa; toisaalta ne ovat selkeästi siitä irtautuneet ja muuttuneet kieliopillisemmiksi.

Adpositioiden käyttöä rektiosuhteen indikaattorina pidetään suomen kielen tutkimuksessa yleensä kielikontaktien aiheuttamana käytön laajentumisena. Tässä tutkimuksessa tuodaan rinnalle vaihtoehtona kielensisäisen kehityksen 
mahdollisuus, jonka tuloksena spatiaalinen adpositio muuttuu rektion merkitsimeksi. Tarkastelu osoittaa perään-adposition osalta, että myös omaperäinen kieliopillistuminen on voinut olla mahdollinen. Perään-adposition kehityskulku noudattaa tavanomaista kieliopillistumispolkua, jossa uusi esiintymiskonteksti virittää pragmaattisen uudelleentulkinnan, joka johtaa uuden merkityksen ja funktion syntyyn. Tarkastelussa käy lisäksi ilmi, että oma ja vieras, kontekstin virittämä natiivi kieliopillistuminen ja kielikontaktien virittämä kieliopillistuminen, ovat voineet olla vuorovaikutuksessa keskenään: ulkoinen vaikutus on vahvistanut jo olemassa olevaa kategoriaa.

Avainsanat: kieltenvälinen vertailu; kieliopillistuminen; kielikontaktin virittämä kieliopillistuminen; adpositiot; rektio; adpositioiden käännöslainaaminen; efter; nach; perään; ruotsi; saksa; suomi 